SUPPORTING INFORMATION

\title{
Photoinduced C-Br Homolysis of 2-Bromobenzophenones and Pschorr Ring Closure of 2-Aroylaryl Radicals to Fluorenones
}

\author{
Jarugu Narasimha Moorthy* and Subhas Samanta \\ Department of Chemistry, Indian Institute of Technology, Kanpur 208016, INDIA
}

Table of Contents:

\begin{tabular}{|c|c|c|}
\hline 1. & General aspect & $\mathrm{S} 2$ \\
\hline 2. & Experimental procedures for the synthesis of ketones, precursor Aldehydes, and spectral data & $\mathrm{S} 2-\mathrm{S} 11$ \\
\hline 3. & General procedure for the photolysis of ketones, and spectral data & S11-S16 \\
\hline 4. & References & S16 \\
\hline 5. & ${ }^{1} \mathrm{H}$ and ${ }^{13} \mathrm{C}$ NMR spectra for 2-bromo-3,5-dimethylbenzoic acid & S17 \\
\hline 6. & ${ }^{1}$ H NMR spectrum for 2-bromo-3,5-dimethylbenzylalcohol & S18 \\
\hline 7. & ${ }^{1} \mathrm{H}$ and ${ }^{13} \mathrm{C}$ NMR spectra for 2-bromo-3,5-dimethylbenzaldehyde & S19 \\
\hline 8. & ${ }^{1} \mathrm{H}$ and ${ }^{13} \mathrm{C}$ NMR spectra for 2,5-dibromo-4-benzoyl-3,6-dimethylbenzophenone $\mathbf{2}$ & $\mathrm{S} 20$ \\
\hline 9. & ${ }^{1} \mathrm{H}$ and ${ }^{13} \mathrm{C}$ NMR spectra for 2-bromo-4'-trifluoromethylbenzophenone $3 \mathbf{c}$ & S21 \\
\hline 10. & ${ }^{1} \mathrm{H}$ and ${ }^{13} \mathrm{C}$ NMR spectra for 2-bromo-3'-methoxybenzophenone $\mathbf{3 d}$ & $\mathrm{S} 22$ \\
\hline 11. & ${ }^{1} \mathrm{H}$ and ${ }^{13} \mathrm{C}$ NMR spectra for 2-bromo-3',5'-dimethoxybenzophenone $3 \mathrm{e}$ & $\mathrm{S} 23$ \\
\hline 12. & ${ }^{1} \mathrm{H}$ and ${ }^{13} \mathrm{C}$ NMR spectra for 2-bromo-3',5'-dimethylbenzophenone $\mathbf{3 f}$ & $\mathrm{S} 24$ \\
\hline 13. & ${ }^{1} \mathrm{H}$ and ${ }^{13} \mathrm{C}$ NMR spectra for 2-bromo-4-methoxybenzophenone $\mathbf{4 a}$ & $\mathrm{S} 25$ \\
\hline 14. & ${ }^{1} \mathrm{H}$ and ${ }^{13} \mathrm{C}$ NMR spectra for 2-bromo-4,4'-dimethoxybenzophenone $\mathbf{4 b}$ & S26 \\
\hline 15. & ${ }^{1} \mathrm{H}$ and ${ }^{13} \mathrm{C}$ NMR spectra for 2-bromo-3',4-dimethoxybenzophenone $4 \mathrm{c}$ & S27 \\
\hline 16. & ${ }^{1} \mathrm{H}$ and ${ }^{13} \mathrm{C}$ NMR spectra for 2-bromo-3',4,5'-trimethoxybenzophenone 4d & S28 \\
\hline 17. & ${ }^{1} \mathrm{H}$ and ${ }^{13} \mathrm{C}$ NMR spectra for 2-bromo-3',5,5'-trimethoxybenzophenone $\mathbf{5}$ & S29 \\
\hline 18. & ${ }^{1} \mathrm{H}$ and ${ }^{13} \mathrm{C}$ NMR spectra for 2-bromo-4,5-dimethoxybenzophenone $\mathbf{6 a}$ & $\mathrm{S} 30$ \\
\hline 19. & ${ }^{1} \mathrm{H}$ and ${ }^{13} \mathrm{C}$ NMR spectra for 2-bromo-3',4,5,5'-tetramethoxybenzophenone $\mathbf{6 b}$ & S31 \\
\hline 20. & ${ }^{1} \mathrm{H}$ and ${ }^{13} \mathrm{C}$ NMR spectra for 2-bromo-3,5-dimethoxybenzophenone 7a & S32 \\
\hline 21. & ${ }^{1} \mathrm{H}$ and ${ }^{13} \mathrm{C}$ NMR spectra for 2-bromo-3,3',5,5'-tetramethoxybenzophenone $7 \mathbf{b}$ & S33 \\
\hline 22. & ${ }^{1} \mathrm{H}$ and ${ }^{13} \mathrm{C}$ NMR spectra for 2-bromo-3,5-dimethylbenzophenone 8a & S34 \\
\hline 23. & ${ }^{1} \mathrm{H}$ and ${ }^{13} \mathrm{C}$ NMR spectra for 2-bromo-3, $5^{\prime}$-dimethoxy-3,5-dimethylbenzophenone $\mathbf{8 b}$ & $\mathrm{S} 35$ \\
\hline 24. & ${ }^{1} \mathrm{H}$ and ${ }^{13} \mathrm{C}$ NMR spectra for 2-bromo-3,5-dimethyl-4'-trifluoromethylbenzophenone 8c & S36 \\
\hline 25. & ${ }^{1} \mathrm{H}$ and ${ }^{13} \mathrm{C}$ NMR spectra for 3-benzoyl-2-bromo-1,4-dimethylfluoren-9-one (2-FI) & S37 \\
\hline 26. & ${ }^{1} \mathrm{H}$ and ${ }^{13} \mathrm{C}$ NMR spectra for 3-methoxyfluoren-9-one (3b-FI) & $\mathrm{S} 38$ \\
\hline 27. & ${ }^{1} \mathrm{H}$ and ${ }^{13} \mathrm{C}$ NMR spectra for 3-trifluoromethylfluoren-9-one (3c-Fl) & S39 \\
\hline 28. & ${ }^{1} \mathrm{H}$ and ${ }^{13} \mathrm{C}$ NMR spectra for 2-methoxyfluoren-9-one (3d-FI) & $\mathrm{S} 40$ \\
\hline 29. & ${ }^{1} \mathrm{H}$ and ${ }^{13} \mathrm{C}$ NMR spectra for 2,4-dimethoxyfluoren-9-one (3e-FI) & S41 \\
\hline 30. & ${ }^{1} \mathrm{H}$ and ${ }^{13} \mathrm{C}$ NMR spectra for 3,6-dimethoxyfluoren-9-one (4b-FI) & S42 \\
\hline 31. & ${ }^{1} \mathrm{H}$ and ${ }^{13} \mathrm{C}$ NMR spectra for 2,6-dimethoxyfluoren-9-one (4c-FI) & $\mathrm{S} 43$ \\
\hline 32. & ${ }^{1} \mathrm{H}$ and ${ }^{13} \mathrm{C}$ NMR spectra for 2,4,6-trimethoxyfluoren-9-one (4d-FI) & S44 \\
\hline 33. & ${ }^{1} \mathrm{H}$ and ${ }^{13} \mathrm{C}$ NMR spectra for 2,4,7-trimethoxyfluoren-9-one (5-FI) & S45 \\
\hline 34. & ${ }^{1} \mathrm{H}$ and ${ }^{13} \mathrm{C}$ NMR spectra for 2,3,5,6-tetramethoxyfluoren-9-one (6b-FI) & $\mathrm{S} 46$ \\
\hline 35. & ${ }^{1} \mathrm{H}$ and ${ }^{13} \mathrm{C}$ NMR spectra for 2,4,5,7-tetramethoxyfluoren-9-one (7b-FI) & S47 \\
\hline 36. & ${ }^{1} \mathrm{H}$ and ${ }^{13} \mathrm{C}$ NMR spectra for 2,4-dimethylfluoren-9-one (8a-FI) & S48 \\
\hline 37. & ${ }^{1} \mathrm{H}$ and ${ }^{13} \mathrm{C}$ NMR spectra for 2,4-dimethoxy-5,7-dimethylfluoren-9-one (8b-FI) & S49 \\
\hline 38. & ${ }^{1} \mathrm{H}$ and ${ }^{13} \mathrm{C}$ NMR spectra for 2,4-dimethoxy-6-trifluoromethylfluoren-9-one (8c-FI) & $\mathrm{S} 50$ \\
\hline 39. & ${ }^{1} \mathrm{H}$ and ${ }^{13} \mathrm{C}$ NMR spectra for 3,5-dimethoxy-4'-trifluoromethylbenzophenone (8c-Bp) & S51 \\
\hline
\end{tabular}




\section{EXPERIMENTAL SECTION}

General Aspects. Tetrahydrofuran (THF) was freshly distilled over sodium/benzophenone prior to use. DCM was distilled over anhyd $\mathrm{CaH}_{2}$ prior to use. The progress of reaction in each case was monitored by analytical thin layer chromatography (TLC) using aluminum sheets pre-coated with silica gel (Merck). Column chromatography was conducted with silica gel 60-120 mesh (Souvenier Chemicals, Bhiwandi). The melting points were determined with a JSGW melting point apparatus and are uncorrected. ${ }^{1} \mathrm{H}$ and ${ }^{13} \mathrm{C}$ NMR spectra were recorded on a JEOL-Lambda (400 MHz) spectrometer using $\mathrm{CDCl}_{3}$ as a solvent. IR spectra were recorded on a Bruker Vector 22 FT-IR spectrophotometer. Mass spectral analyses were carried out with Waters ESI-Q ${ }^{\text {TOF }}$ Instrument. Preparative photolyses were carried out in a Luzchem photoreactor.

2-Bromobenzaldehyde (Sigma-Aldrich) was used as received. 2-Bromobenzophenone 3a was prepared according to the reported procedure. ${ }^{1}$

\section{General Procedure for the Synthesis of Ketones 3b, 3d-f, 5, 6a,b and 7a,b by Bromination-} Grignard-PCC Oxidation Sequence

A representative procedure for the synthesis of 2-bromo-4,5-dimethoxybenzophenone $\mathbf{6 a}$ is described below. All other ketones were synthesized in a similar manner.

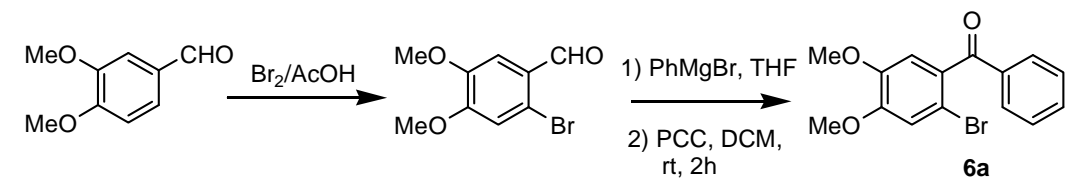

To a solution of 3,4-dimethoxybenzaldehyde $(20.0 \mathrm{mmol})$ in acetic acid $(34.0 \mathrm{~mL})$, a solution of bromine $(41.7 \mathrm{mmol})$ in acetic acid $(13.0 \mathrm{~mL})$ was added slowly through an addition funnel at ice-cold conditions. The resulting reaction mixture was allowed to stir at room temperature overnight. Addition of ice-cold water $(34 \mathrm{~mL})$ to the reaction mixture led to a solid precipitate, which was filtered and thoroughly washed with cold water. The crude product was recrystallized from methanol-water mixture $(6: 1)$ to yield pure colorless crystalline 2-bromo-4,5- 
dimethoxybenzaldehyde (73\%). A similar procedure was employed for the preparation of 2 bromo-5-methoxybenzaldehyde and 2-bromo-3,5-dimethoxybenzaldehyde.

To an ice-cold anhyd THF (5.0 mL) solution of 2-bromo-4,5-dimethoxybenzaldehyde (6.1 mmol) contained in an oven-dried round bottom flask, was slowly added, under a nitrogen gas atmosphere, a THF solution of aryl magnesium bromide prepared from $\mathrm{Mg}$ turnings $(7.3 \mathrm{mmol})$ and bromobenzene $(6.7 \mathrm{mmol})$ in the presence of a catalytic amount of iodine or 1,2dibromoethane in dry THF $(5 \mathrm{~mL})$. The reaction mixture was stirred at room temperature for $2 \mathrm{~h}$ and then quenched with saturated $\mathrm{NH}_{4} \mathrm{Cl}$. The solvent was removed in vacuo and the resulting reaction mixture was extracted with ethyl acetate. The organic layer was washed with brine, dried over anhyd $\mathrm{Na}_{2} \mathrm{SO}_{4}$, filtered and the solvent was removed in vacuo. The residue was subjected to a short pad Silica-gel column chromatography (25\% EtOAc/pet. ether) to obtain the corresponding alcohol (72\%).

To an ice-cold solution of above alcohol $(4.4 \mathrm{mmol})$ in dry DCM $(15 \mathrm{~mL})$ was added $4-\AA$ molecular sieves followed by PCC $(6.6 \mathrm{mmol})$. The reaction mixture was vigorously stirred at this temperature for $10 \mathrm{~min}$ and then stirred at room temperature for additional $2 \mathrm{~h}$. Subsequently, the reaction mixture was filtered over a short pad of silica-gel with $50 \%$ chloroform/pet. ether to obtain 2-bromo-4,5-dimethoxybenzophenone 6a (92\%).

2-Bromo-4,5-dimethoxybenzaldehyde ${ }^{2}$ : Yield 73\%, colorless crystalline solid; mp $154-155{ }^{\circ} \mathrm{C}$ (lit. 148-150 ${ }^{\circ} \mathrm{C}$ ); IR (Neat) $\mathrm{cm}^{-1}$ 1670, 1590, 1507; NMR ( $\left.\mathrm{CDCl}_{3}, 400 \mathrm{MHz}\right) \delta 3.90$ (s, 3H), 3.95 (s, 3H), $7.04(\mathrm{~s}, 1 \mathrm{H}), 7.39(\mathrm{~s}, 1 \mathrm{H}), 10.17(\mathrm{~s}, 1 \mathrm{H})$.

2-Bromo-5-methoxybenzaldehyde ${ }^{3}$ : Yield 73\%, colorless crystalline solid; mp $74-76{ }^{\circ} \mathrm{C}$ (lit. $\left.78-80{ }^{\circ} \mathrm{C}\right)$; IR (Neat) $\mathrm{cm}^{-1} 1676,1569 \mathrm{~cm}^{-1} ;{ }^{1} \mathrm{H} \mathrm{NMR}\left(\mathrm{CDCl}_{3}, 400 \mathrm{MHz}\right) \delta 3.84(\mathrm{~s}, 3 \mathrm{H}), 7.03$ (dd, $\left.J_{1}=8.8 \mathrm{~Hz}, J_{2}=3.2 \mathrm{~Hz}, 1 \mathrm{H}\right), 7.41(\mathrm{~d}, J=3.2 \mathrm{~Hz}, 1 \mathrm{H}), 7.52(\mathrm{~d}, J=8.8 \mathrm{~Hz}, 1 \mathrm{H}), 10.17(\mathrm{~s}, 1 \mathrm{H})$.

2-Bromo-3,5-dimethoxybenzaldehyde ${ }^{4}$ : Yield $63 \%$, colorless crystalline solid; mp $110-112{ }^{\circ} \mathrm{C}$ (lit. 115-116 ${ }^{\circ} \mathrm{C}$ ); IR (Neat) $\mathrm{cm}^{-1} 1678,1589 ;{ }^{1} \mathrm{H}$ NMR ( $\left.\mathrm{CDCl}_{3}, 400 \mathrm{MHz}\right) \delta 3.85$ (s, 3H), 3.91 (s, $3 \mathrm{H}), 6.71(\mathrm{~d}, J=2.9 \mathrm{~Hz}, 1 \mathrm{H}), 7.04(\mathrm{~d}, J=2.9 \mathrm{~Hz}, 1 \mathrm{H}), 10.41(\mathrm{~s}, 1 \mathrm{H})$. 
2-Bromo-4'-methoxybenzophenone (3b) ${ }^{5}$ : Yield 98\%, colorless crystalline solid; mp 90-92 ${ }^{\circ} \mathrm{C}$; IR (KBr) cm ${ }^{-1} 1656,1598 ;{ }^{1} \mathrm{H}$ NMR $\left(\mathrm{CDCl}_{3}, 400 \mathrm{MHz}\right) \delta 3.88(\mathrm{~s}, 3 \mathrm{H}), 6.94(\mathrm{~d}, J=9.0 \mathrm{~Hz}, 2 \mathrm{H})$, $7.31-7.36(\mathrm{~m}, 2 \mathrm{H}), 7.41\left(\mathrm{td}, J_{1}=7.3 \mathrm{~Hz}, J_{2}=1.2 \mathrm{~Hz}, 1 \mathrm{H}\right), 7.64(\mathrm{~d}, J=7.3 \mathrm{~Hz}, 1 \mathrm{H}), 7.79(\mathrm{~d}, J=$ $9.0 \mathrm{~Hz}, 2 \mathrm{H}) ;{ }^{13} \mathrm{C} \mathrm{NMR}\left(\mathrm{CDCl}_{3}, 100 \mathrm{MHz}\right) \delta 55.5,113.9,119.4,127.1,128.7,129.1,130.8$, 132.6, 133.0, 141.1, 164.1, 194.4.

2-Bromo-3'-methoxybenzophenone (3d): Yield 99\%, colorless crystalline solid; mp 83-85 ${ }^{\circ} \mathrm{C}$; IR (KBr) cm ${ }^{-1} 1662,1590 ;{ }^{1} \mathrm{H}$ NMR $\left(\mathrm{CDCl}_{3}, 400 \mathrm{MHz}\right) \delta 3.78$ (s, 3H), 7.06-7.09 (m, 1H), 7.19$7.21(\mathrm{~m}, 1 \mathrm{H}), 7.25-7.29(\mathrm{~m}, 3 \mathrm{H}), 7.32-7.37(\mathrm{~m}, 2 \mathrm{H}), 7.55-7.58(\mathrm{~m}, 1 \mathrm{H}) ;{ }^{13} \mathrm{C} \mathrm{NMR}\left(\mathrm{CDCl}_{3}, 100\right.$ MHz) $\delta 55.4,113.6,119.5,120.4,123.5,127.1,128.9,129.5,131.1,133.2,137.4,140.6,159.8$, 195.7; ESI-MS ${ }^{+}$m/z Calcd for $\mathrm{C}_{14} \mathrm{H}_{11} \mathrm{BrO}_{2} 291.0020$ [M+H], found 291.0023 .

2-Bromo-3',5'-dimethoxybenzophenone (3e): Yield 82\%, colorless crystalline solid; mp 75-76 ${ }^{\circ} \mathrm{C}$; IR $(\mathrm{KBr}) \mathrm{cm}^{-1} 1663,1593 ;{ }^{1} \mathrm{H}$ NMR $\left(\mathrm{CDCl}_{3}, 400 \mathrm{MHz}\right) \delta 3.81(\mathrm{~s}, 6 \mathrm{H}), 6.69$ (t, J=2.2 Hz, $1 \mathrm{H}), 6.94(\mathrm{~d}, J=2.2 \mathrm{~Hz}, 2 \mathrm{H}), 7.32-7.37(\mathrm{~m}, 2 \mathrm{H}), 7.39\left(\mathrm{td}, J_{1}=7.0 \mathrm{~Hz}, J_{2}=1.2 \mathrm{~Hz}, 1 \mathrm{H}\right), 7.63$ $(\mathrm{d}, \quad J=7.0 \mathrm{~Hz}, 1 \mathrm{H}) ;{ }^{13} \mathrm{C} \mathrm{NMR}\left(\mathrm{CDCl}_{3}, 100 \mathrm{MHz}\right) \delta 55.6,106.1,108.0,119.5,127.1,128.8$, 131.1, 133.1, 138.0, 140.5, 160.8, 195.6; ESI-MS ${ }^{+} \mathrm{m} / \mathrm{z}$ Calcd for $\mathrm{C}_{15} \mathrm{H}_{13} \mathrm{BrO}_{3} 321.0126$ [M+H], found 321.0125 .

2-Bromo-3',5'-dimethylbenzophenone (3f): Yield 98\%, colorless liquid; IR (neat) $\mathrm{cm}^{-1} 1672$, 1603; ${ }^{1} \mathrm{H} \mathrm{NMR}\left(\mathrm{CDCl}_{3}, 400 \mathrm{MHz}\right) \delta 2.35(\mathrm{~s}, 6 \mathrm{H}), 7.24(\mathrm{~s}, 1 \mathrm{H}), 7.30-7.44(\mathrm{~m}, 5 \mathrm{H}), 7.65(\mathrm{~d}, J=$ $8.0 \mathrm{~Hz}, 1 \mathrm{H}) ;{ }^{13} \mathrm{C} \mathrm{NMR}\left(\mathrm{CDCl}_{3}, 100 \mathrm{MHz}\right) \delta 21.1,119.5,127.1,128.0,128.9,130.9,133.1$, 135.5, 136.1, 138.3, 141.0, 196.2; ESI-MS ${ }^{+} \mathrm{m} / \mathrm{z}$ Calcd for $\mathrm{C}_{15} \mathrm{H}_{13} \mathrm{BrO} 289.0228[\mathrm{M}+\mathrm{H}]$, found 289.0227.

2-Bromo-3',5,5'-trimethoxybenzophenone (5): Yield 74\%, colorless crystalline solid; mp 72$74{ }^{\circ} \mathrm{C}$; IR (neat) $\mathrm{cm}^{-1} 1674,1594 ;{ }^{1} \mathrm{H}$ NMR $\left(\mathrm{CDCl}_{3}, 400 \mathrm{MHz}\right) \delta 3.80(\mathrm{~s}, 3 \mathrm{H}), 3.81(\mathrm{~s}, 6 \mathrm{H}), 6.69$ $(\mathrm{t}, J=2.2 \mathrm{~Hz}, 1 \mathrm{H}), 6.85(\mathrm{~d}, J=2.9 \mathrm{~Hz}, 1 \mathrm{H}), 6.89\left(\mathrm{dd}, J_{1}=8.8 \mathrm{~Hz}, J_{2}=2.9 \mathrm{~Hz}, 1 \mathrm{H}\right), 6.96(\mathrm{~d}, J=$ $2.2 \mathrm{~Hz}, 2 \mathrm{H}), 7.49(\mathrm{~d}, J=8.8 \mathrm{~Hz}, 1 \mathrm{H}) ;{ }^{13} \mathrm{C} \mathrm{NMR}\left(\mathrm{CDCl}_{3}, 100 \mathrm{MHz}\right) \delta 55.6(\times 2), 106.1,108.0$, 
109.6, 114.0, 117.3, 133.9, 137.7, 141.3, 158.6, 160.8, 195.3; ESI-MS ${ }^{+} \mathrm{m} / \mathrm{z}$ Calcd for $\mathrm{C}_{16} \mathrm{H}_{15} \mathrm{BrO}_{4} 351.0231[\mathrm{M}+\mathrm{H}]$, found 351.0231 .

2-Bromo-4,5-dimethoxybenzophenone (6a): Yield 94\%, colorless crystalline solid; mp 90-92 ${ }^{\circ} \mathrm{C}$; IR (KBr) cm ${ }^{-1} 1660,1595 ;{ }^{1} \mathrm{H} \mathrm{NMR}\left(\mathrm{CDCl}_{3}, 400 \mathrm{MHz}\right) \delta 3.85$ (s, 3H), $3.94(\mathrm{~s}, 3 \mathrm{H}), 6.89$ (s, 1H), $7.08(\mathrm{~s}, 1 \mathrm{H}), 7.47$ (t, $J=7.6 \mathrm{~Hz}, 2 \mathrm{H}), 7.60$ (t, $J=7.6 \mathrm{~Hz}, 1 \mathrm{H})$ ), 7.82 (d, $J=8.3 \mathrm{~Hz}, 2 \mathrm{H})$; ${ }^{13} \mathrm{C} \mathrm{NMR}\left(\mathrm{CDCl}_{3}, 100 \mathrm{MHz}\right) \delta 56.2,56.3,110.9,112.2,115.7,128.5,130.2,132.3,133.5,136.6$, 148.2, 150.8, 195.7; ESI-MS ${ }^{+}$m/z Calcd for $\mathrm{C}_{15} \mathrm{H}_{13} \mathrm{BrO}_{3} 321.0126[\mathrm{M}+\mathrm{H}]$, found 321.0125 .

2-Bromo-3',4,5,5'-tetramethoxybenzophenone (6b): Yield 99\%, colorless gummy liquid; IR (neat) $\mathrm{cm}^{-1} 1667,1593 ;{ }^{1} \mathrm{H}$ NMR $\left(\mathrm{CDCl}_{3}, 400 \mathrm{MHz}\right) \delta 3.81(\mathrm{~s}, 6 \mathrm{H}), 3.85(\mathrm{~s}, 3 \mathrm{H}), 3.93(\mathrm{~s}, 3 \mathrm{H})$, $6.68(\mathrm{t}, J=2.4 \mathrm{~Hz}, 1 \mathrm{H}), 6.87(\mathrm{~s}, 1 \mathrm{H}), 6.94(\mathrm{~d}, J=2.4 \mathrm{~Hz}, 2 \mathrm{H}), 7.06(\mathrm{~s}, 1 \mathrm{H})) ;{ }^{13} \mathrm{C} \mathrm{NMR}\left(\mathrm{CDCl}_{3}\right.$, $100 \mathrm{MHz}) \delta 55.6,56.2,56.3,105.9,108.0,110.9,112.1,115.7,132.3,138.5,148.1,150.8$, 160.8, 195.3; ESI-MS ${ }^{+}$m/z Calcd for $\mathrm{C}_{17} \mathrm{H}_{17} \mathrm{BrO}_{5} 381.0337$ [M+H], found 381.0338.

2-Bromo-3,5-dimethoxybenzophenone (7a): Yield 98\%, colorless crystalline solid; mp 73-75 ${ }^{\circ} \mathrm{C}$; IR (KBr) cm ${ }^{-1} 1666,1582,1344 ;{ }^{1} \mathrm{H}$ NMR $\left(\mathrm{CDCl}_{3}, 400 \mathrm{MHz}\right) \delta 3.80(\mathrm{~s}, 3 \mathrm{H}), 3.92(\mathrm{~s}, 3 \mathrm{H})$, $6.47(\mathrm{~d}, J=2.7 \mathrm{~Hz}, 1 \mathrm{H}), 6.59$ (d, $J=2.7 \mathrm{~Hz}, 1 \mathrm{H}), 7.46$ (t, $J=7.8 \mathrm{~Hz}, 2 \mathrm{H}), 7.60$ (t, $J=7.3 \mathrm{~Hz}$, 1H) ), $7.84(\mathrm{~d}, J=7.8 \mathrm{~Hz}, 2 \mathrm{H}) ;{ }^{13} \mathrm{C} \mathrm{NMR}\left(\mathrm{CDCl}_{3}, 100 \mathrm{MHz}\right) \delta 55.7,56.4,99.7,100.8,104.2$, 128.6, 130.2, 133.8, 135.7, 142.5, 156.8, 160.0, 195.7; ESI-MS ${ }^{+} \mathrm{m} / \mathrm{z}$ Calcd for $\mathrm{C}_{15} \mathrm{H}_{13} \mathrm{BrO}_{3}$ $321.0126[\mathrm{M}+\mathrm{H}]$, found 321.0126 .

2-Bromo-3,3',5,5'-tetramethoxybenzophenone (7b): Yield 85\%, colorless crystalline solid; mp 132-134 ${ }^{\circ} \mathrm{C}$; IR (neat) $\mathrm{cm}^{-1} 1674,1589,1341 ;{ }^{1} \mathrm{H} \mathrm{NMR}\left(\mathrm{CDCl}_{3}, 400 \mathrm{MHz}\right) \delta 3.79$ (s, 3H), 3.80 (s, 6H), $3.90(\mathrm{~s}, 3 \mathrm{H}), 6.44(\mathrm{~d}, J=2.7 \mathrm{~Hz}, 1 \mathrm{H}), 6.56(\mathrm{~d}, J=2.7 \mathrm{~Hz}, 1 \mathrm{H}), 6.68$ (t, $J=2.2 \mathrm{~Hz}, 1 \mathrm{H})$, $7.97(\mathrm{~d}, J=2.2 \mathrm{~Hz}, 2 \mathrm{H})) ;{ }^{13} \mathrm{C} \mathrm{NMR}\left(\mathrm{CDCl}_{3}, 100 \mathrm{MHz}\right) \delta 55.6(\mathrm{x} 2), 56.4,99.7,100.8,104.3$, 106.1, 108.0, 137.7, 142.5, 156.8, 159.9, 160.8, 195.4; ESI-MS ${ }^{+} \mathrm{m} / \mathrm{z}$ Calcd for $\mathrm{C}_{17} \mathrm{H}_{17} \mathrm{BrO}_{5}$ $381.0337[\mathrm{M}+\mathrm{H}]$, found 381.0337 . 


\section{Synthesis of 2,5-Dibromo-4-benzoyl-3,6-dimethylbenzophenone 2}

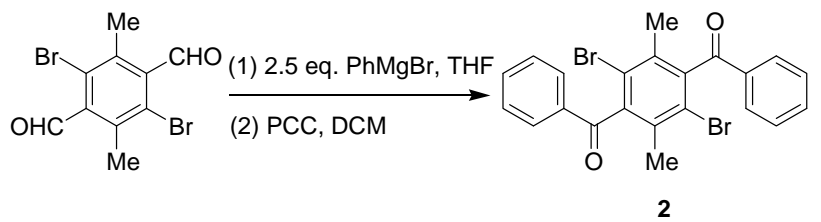

The precursor aldehyde 2,5-dibromo-3,6-dimethylterephthalaldehyde was prepared according to the reported procedures. ${ }^{6}$ A 2-fold Grignard reaction using $\mathrm{PhMgBr}$ with the dialdehyde, as described above, yielded dialcohol (87\%). The dialcohol was further subjected to PCC oxidation to yield diketone $2(80 \%)$; colorless crystalline solid; mp $274-276{ }^{\circ} \mathrm{C}$; IR $(\mathrm{KBr}) \mathrm{cm}^{-1} 1672,1593$; ${ }^{1} \mathrm{H} \mathrm{NMR}\left(\mathrm{CDCl}_{3}, 400 \mathrm{MHz}\right) \delta 2.24(\mathrm{~s}, 6 \mathrm{H}), 7.51(\mathrm{t}, J=7.6 \mathrm{~Hz}, 4 \mathrm{H}), 7.65(\mathrm{t}, J=7.3 \mathrm{~Hz}, 2 \mathrm{H})$, $7.87(\mathrm{~d}, J=7.3 \mathrm{~Hz}, 4 \mathrm{H}) ;{ }^{13} \mathrm{C} \mathrm{NMR}\left(\mathrm{CDCl}_{3}, 100 \mathrm{MHz}\right) \delta 20.2,121.3,129.1,129.6,129.8,134.4$, 135.2, 142.3, 195.8; ESI-MS ${ }^{+}$m/z Calcd for $\mathrm{C}_{22} \mathrm{H}_{16} \mathrm{Br}_{2} \mathrm{O}_{2} 470.9595$ [M+H], found 470.9594 .

\section{General Procedure for the Synthesis of Ketones 4a-d}

A representative procedure for the Synthesis of 2-bromo-3,3',5'-trimethoxybenzophenone 4d is described below.



To a solution of 3-bromoanisole $(13.4 \mathrm{mmol})$ in dry DCM $(50.0 \mathrm{~mL})$ was added dropwise $\mathrm{TiCl}_{4}(22.4 \mathrm{mmol})$ at $0{ }^{0} \mathrm{C}$ under nitrogen gas atmosphere. Dichloromethyl methyl ether (14.7 mmol) was added dropwise to the reaction mixture at ice-cold conditions over a period of 20 min. After stirring for additional $30 \mathrm{~min}$ at this temperature, it was allowed to reach room 
temperature and stirred for additional $45 \mathrm{~min}$. The reaction mixture was poured into a mixture of $7.0 \mathrm{ml}$ of $\mathrm{Conc} \mathrm{HCl}$ and crushed-ice, and the organic matter was extracted with chloroform. The combined extract was washed with water, brine, dried over anhyd $\mathrm{Na}_{2} \mathrm{SO}_{4}$ and concentrated in vacuo. The residue was subjected to a silica-gel column chromatography to obtain an inseparable mixture of two regioisomeric aromatic aldehydes (80\%).

The reaction of the mixture of aldehydes $(5.6 \mathrm{mmol})$ with 3,5-dimethoxyphenyl magnesium bromide, which was prepared from 3,5-dimethoxybromobenzene (8.4 mmol), Mg-turning (9.5 mmol) and catalytic amount of 1,2-dibromoethane in anhyd THF, yielded a mixture of two regioisomeric alcohols in a quantitative yield. The mixture of alcohols was further subjected to PCC oxidation, as described above, to obtain a mixture of regioisomeric benzophenone derivatives. The latter were separated by a careful Silica-gel column chromatography. The required regioisomer $\mathbf{4 d}$ was obtained in $52 \%$ yield.

2-Bromo-4-methoxybenzophenone (4a): Yield 60\%, colorless crystalline solid; mp 86-88 ${ }^{\circ} \mathrm{C}$; IR (Neat) cm ${ }^{-1} 1665,1598 ;{ }^{1} \mathrm{H}$ NMR $\left(\mathrm{CDCl}_{3}, 400 \mathrm{MHz}\right) \delta 3.87(\mathrm{~s}, 3 \mathrm{H}), 6.92\left(\mathrm{dd}, J_{1}=8.6 \mathrm{~Hz}, J_{2}\right.$ $=2.4 \mathrm{~Hz}, 1 \mathrm{H}), 7.19(\mathrm{~d}, J=2.4 \mathrm{~Hz}, 1 \mathrm{H}), 7.30(\mathrm{~d}, J=8.6 \mathrm{~Hz}, 1 \mathrm{H}), 7.46(\mathrm{t}, J=7.8 \mathrm{~Hz}, 2 \mathrm{H}), 7.59$ $(\mathrm{t}, J=7.6 \mathrm{~Hz}, 1 \mathrm{H}), 7.80(\mathrm{~d}, J=7.8 \mathrm{~Hz}, 2 \mathrm{H}) ;{ }^{13} \mathrm{C} \mathrm{NMR}\left(\mathrm{CDCl}_{3}, 100 \mathrm{MHz}\right) \delta 55.7,113.0,118.7$, $121.1,128.5,130.2,131.0,132.6,133.3,136.9,161.3,195.5 ;$ ESI-MS $^{+} \mathrm{m} / \mathrm{z}$ Calcd for $\mathrm{C}_{14} \mathrm{H}_{11} \mathrm{BrO}_{2} 291.0020[\mathrm{M}+\mathrm{H}]$, found 291.0020.

2-Bromo-4,4'-dimethoxybenzophenone (4b): Yield 60\%, colorless crystalline solid; mp 46-48


$\left(\mathrm{dd}, J_{1}=8.6 \mathrm{~Hz}, J_{2}=2.4 \mathrm{~Hz}, 1 \mathrm{H}\right), 6.93(\mathrm{~d}, J=8.8 \mathrm{~Hz}, 2 \mathrm{H}), 7.17(\mathrm{~d}, J=2.4 \mathrm{~Hz}, 1 \mathrm{H}), 7.29(\mathrm{~d}, J=$ $8.6 \mathrm{~Hz}, 1 \mathrm{H}), 7.78(\mathrm{~d}, J=8.8 \mathrm{~Hz}, 2 \mathrm{H})) ;{ }^{13} \mathrm{C} \mathrm{NMR}\left(\mathrm{CDCl}_{3}, 100 \mathrm{MHz}\right) \delta 55.5,55.7,113.0,113.7$, 118.5, 120.8, 129.7, 130.5, 132.6, 133.1, 161.0, 163.8, 194.2; ESI-MS $^{+} \mathrm{m} / \mathrm{z}$ Calcd for $\mathrm{C}_{15} \mathrm{H}_{13} \mathrm{BrO}_{3} 321.0126[\mathrm{M}+\mathrm{H}]$, found 321.0125 .

2-Bromo-3',4-dimethoxybenzophenone (4c): Yield 62\%, white crystalline solid; mp 70-71 ${ }^{\circ} \mathrm{C}$; IR $(\mathrm{KBr}) \mathrm{cm}^{-1} 1668,1596 ;{ }^{1} \mathrm{H} \mathrm{NMR}\left(\mathrm{CDCl}_{3}, 400 \mathrm{MHz}\right) \delta 3.85(\mathrm{~s}, 3 \mathrm{H}), 3.87(\mathrm{~s}, 3 \mathrm{H}), 6.92\left(\mathrm{dd}, J_{1}\right.$ $\left.=8.6 \mathrm{~Hz}, J_{2}=2.4 \mathrm{~Hz}, 1 \mathrm{H}\right), 7.14\left(\mathrm{dd}, J_{1}=8.0 \mathrm{~Hz}, J_{2}=2.6 \mathrm{~Hz}, 1 \mathrm{H}\right), 7.18(\mathrm{~d}, J=2.4 \mathrm{~Hz}, 1 \mathrm{H})$, 7.28-7.36 (m, 3H), 7.441(d, $J=2.6 \mathrm{~Hz}, 1 \mathrm{H}) ;{ }^{13} \mathrm{C} \mathrm{NMR}\left(\mathrm{CDCl}_{3}, 100 \mathrm{MHz}\right) \delta 55.5,55.7,112.9$, 
113.7, 118.7, 120.0, 121.1, 123.4, 129.4, 130.9, 132.6, 138.2, 159.7, 161.3, 195.4; ESI-MS ${ }^{+} \mathrm{m} / \mathrm{z}$ Calcd for $\mathrm{C}_{15} \mathrm{H}_{13} \mathrm{BrO}_{3} 321.0126[\mathrm{M}+\mathrm{H}]$, found 321.0127 .

2-Bromo-3',4,5'-trimethoxybenzophenone (4d): Yield 52\%, white crystalline solid; mp 85-87 ${ }^{\circ} \mathrm{C}$; IR ( $\left.\mathrm{KBr}\right) \mathrm{cm}^{-1} 1666,1593 ;{ }^{1} \mathrm{H}$ NMR $\left(\mathrm{CDCl}_{3}, 400 \mathrm{MHz}\right) \delta 3.81$ (s, 6H), $3.86(\mathrm{~s}, 3 \mathrm{H}), 6.67(\mathrm{t}$, $J=2.2 \mathrm{~Hz}, 1 \mathrm{H}), 6.91\left(\mathrm{dd}, J_{1}=8.5 \mathrm{~Hz}, J_{2}=2.4 \mathrm{~Hz}, 1 \mathrm{H}\right), 6.93(\mathrm{~d}, J=2.2 \mathrm{~Hz}, 2 \mathrm{H}), 7.18(\mathrm{~d}, J=2.4$ $\mathrm{Hz}, 2 \mathrm{H}), 7.31(\mathrm{~d}, J=8.5 \mathrm{~Hz}, 1 \mathrm{H}) ;{ }^{13} \mathrm{C} \mathrm{NMR}\left(\mathrm{CDCl}_{3}, 100 \mathrm{MHz}\right) \delta 55.6,55.7,105.7,108.0$, $112.9,118.7,121.1,130.9,132.5,138.8,160.7,161.3,195.2 ;$ ESI-MS $^{+} \mathrm{m} / \mathrm{z}$ Calcd for $\mathrm{C}_{16} \mathrm{H}_{15} \mathrm{BrO}_{4} 351.0231[\mathrm{M}+\mathrm{H}]$, found 351.0232 .

\section{General Procedure for the Synthesis of Ketones $3 \mathrm{c}$ and $8 \mathrm{c}$}

The procedure for the synthesis of 2-bromo-3,5-dimethyl-4'-trifluoromethylbenzophenone $\mathbf{8 c}$ is described below. A similar procedure was followed for the synthesis of ketone $\mathbf{3 c}$.



To an ice-cold solution of 4-trifluoromethylbromobenzene $(1.2 \mathrm{mmol})$ in dry THF $(3 \mathrm{~mL})$ contained in a 2-necked round bottom flask was added, under a nitrogen gas atmosphere, a THF solution of $i-\mathrm{PrMgCl} . \mathrm{LiCl}(1.2 \mathrm{mmol}, 0.56 \mathrm{M})$ dropwise; the latter was prepared from $i-\mathrm{PrCl}$ (40.8 mmol), Mg-turnings (44.8 mmol) and $\mathrm{LiCl}(40.8 \mathrm{mmol})$ in presence of catalytic amount of iodine in dry THF $(40 \mathrm{~mL})$ solvent and was standardized. After stirring the reaction mixture at 0 ${ }^{0} \mathrm{C}$ for 2-3 h, a solution of 2-bromo-3,5-dimethylbenzaldehyde in THF was introduced into the reaction mixture and stirred at room temperature for $2 \mathrm{~h}$. Subsequently, the reaction was quenched with saturated $\mathrm{NH}_{4} \mathrm{Cl}$. The solvent was removed in vacuo and the resulting reaction mixture was extracted with ethyl acetate. The organic layer was washed with brine, dried over anhyd $\mathrm{Na}_{2} \mathrm{SO}_{4}$, filtered and the solvent removed in vacuo. The residue was subjected to a short pad Silica-gel column chromatography ( $25 \%$ EtOAc/pet. ether) to obtain the corresponding 
alcohol (35-40\%), which was further subjected to PCC oxidation to yield the ketone $8 \mathbf{c}$ in $92 \%$ yield.

2-Bromo-4'-trifluoromethylbenzophenone (3c): Yield $84 \%$, colorless liquid; IR (Neat) $\mathrm{cm}^{-1}$ $1681 ;{ }^{1} \mathrm{H} \mathrm{NMR}\left(\mathrm{CDCl}_{3}, 400 \mathrm{MHz}\right) \delta$ 7.35-7.48 (m, 3H), $7.67\left(\mathrm{dd}, J_{1}=8.0 \mathrm{~Hz}, J_{2}=1.2 \mathrm{~Hz}, 1 \mathrm{H}\right)$, $7.73(\mathrm{~d}, J=8.4 \mathrm{~Hz}, 2 \mathrm{H}), 7.92(\mathrm{~d}, J=8.0 \mathrm{~Hz}, 2 \mathrm{H}) ;{ }^{13} \mathrm{C} \mathrm{NMR}\left(\mathrm{CDCl}_{3}, 100 \mathrm{MHz}\right) \delta 119.5,125.7$, $125.7,127.4,129.2,130.4,131.7,133.4,138.9,139.8,195.0 ; \mathrm{ESI}_{-} \mathrm{MS}^{+} \mathrm{m} / \mathrm{z}$ Calcd for $\mathrm{C}_{14} \mathrm{H}_{8} \mathrm{BrF}_{3} \mathrm{O} 328.9788[\mathrm{M}+\mathrm{H}]$, found 328.9782 .

2-Bromo-3,5-dimethyl-4'-trifluoromethylbenzophenone $\quad$ (8c): Yield 92\%, colorless crystalline solid; mp 82-84 ${ }^{\circ} \mathrm{C}$; IR ( $\left.\mathrm{KBr}\right) \mathrm{cm}^{-1} 1676 ;{ }^{1} \mathrm{H} \mathrm{NMR}\left(\mathrm{CDCl}_{3}, 400 \mathrm{MHz}\right) \delta 2.30$ (s, 3H), 2.43 (s, 3H), 6.96 (s, 1H), 7.22 (s, 1H), 7.72 (d, $J=8.3 \mathrm{~Hz}, 2 \mathrm{H}), 7.93$ (d, $J=8.3 \mathrm{~Hz}, 2 \mathrm{H}) ;{ }^{13} \mathrm{C}$ $\operatorname{NMR}\left(\mathrm{CDCl}_{3}, 100 \mathrm{MHz}\right) \delta 20.7,22.9,118.0,125.61,125.64,126.8,130.3,133.2,137.4,139.0$, 139.1, 140.4, 195.5; ESI-MS ${ }^{+}$m/z Calcd for $\mathrm{C}_{16} \mathrm{H}_{12} \mathrm{BrF}_{3} \mathrm{O} 357.0101[\mathrm{M}+\mathrm{H}]$, found 357.0103 .

\section{General Procedure for the Synthesis of Ketones 8a and 8b}

A representative procedure for the synthesis of 2-bromo-3, $5^{\prime}$-dimethoxy-3,5dimethylbenzophenone $\mathbf{8 b}$ from 3,5-dimethylbenzoic acid is described below.
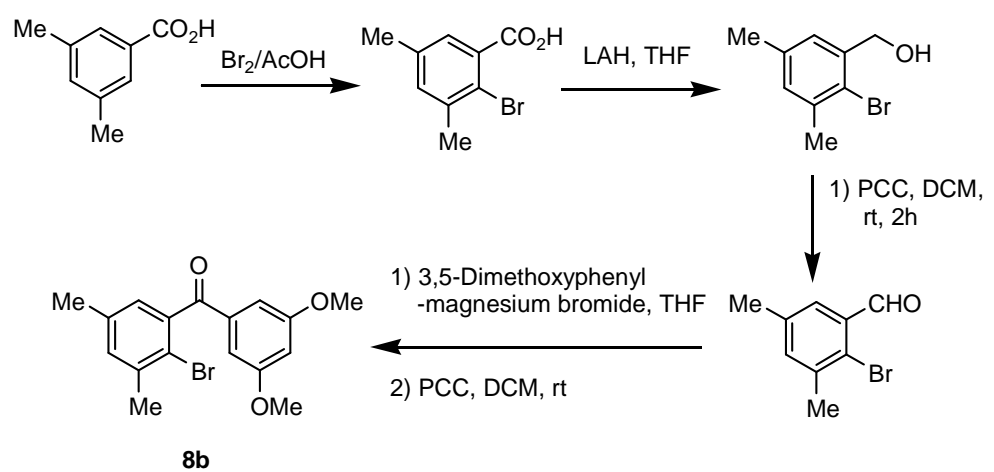

A solution of bromine $(50.0 \mathrm{mmol})$ in acetic acid $(10.0 \mathrm{~mL})$ was added slowly through an addition funnel to a solution of 3,5-dimethylbenzaldehyde $(16.7 \mathrm{mmol})$ in acetic acid $(15.0 \mathrm{~mL})$. The resulting reaction mixture was allowed to stir at room temperature over a period of $72 \mathrm{~h}$. The 
reaction was monitored by TLC analysis. The precipitate obtained, after addition of ice cold water $(30 \mathrm{ml})$ to the reaction mixture, was filtered and thoroughly washed with ice-cold water. The crude product was further recrystallized from methanol to yield colorless crystalline 2bromo-3,5-dimethylbenzoic acid (84\%).

To lithium aluminum hydride $(10.3 \mathrm{mmol})$ suspended in anhyd THF $(10.0 \mathrm{~mL})$ under a nitrogen gas atmosphere, was added a solution of 2-bromo-3,5-dimethylbenzoic acid (9.4 mmol) in anhyd THF $(15.0 \mathrm{~mL})$ dropwise. During the addition, significant heating was observed. After completion of the addition of acid, the reaction mixture was allowed to stir at $\mathrm{rt}$ for $4 \mathrm{~h}$. The solution was cooled with an ice bath and the excess of LAH was destroyed by careful addition of water. When no further evolution of $\mathrm{H}_{2}$ was observed, the precipitate was dissolved by the addition of $10 \mathrm{~mL}$ of dil. $\mathrm{H}_{2} \mathrm{SO}_{4}$. Subsequently, the reaction mixture was extracted with DCM and washed with brine. The organic layer was dried over anhyd $\mathrm{Na}_{2} \mathrm{SO}_{4}$ and the solvent was evaporated in vacuo. The crude product obtained was subjected to short pad Silica-gel column chromatography (25\% EtOAc/pet. ether) to obtain colorless crystalline alcohol (61\%).

The alcohol thus obtained was further subjected to PCC oxidation, as described above, to yield colorless crystal of 2-bromo-3,5-dimethylbenzaldehyde (yield 84\%).

To a solution of 2-bromo-3,5-dimethylbenzaldehyde in anhyd THF under a $\mathrm{N}_{2}$ gas atmosphere was added a solution of 3,5-dimethoxyphenyl magnesium bromide in THF, which was prepared from 1-bromo-3,5-dimethoxybenzene, Mg-turnings and catalytic amount of 1,2dibromoethane in presence of anhyd THF. The resulting reaction mixture was stirred at room temperature for $2 \mathrm{~h}$. Usual workup followed by a Silica-gel column chromatography yielded the alcohol (80\%), PCC oxidation of which led to ketone 8a (97\%). A similar protocol was used for the synthesis of ketone $\mathbf{8 b}$.

2-Bromo-3,5-dimethylbenzoic acid: Yield 84\%, colorless crystalline solid; mp 143-144 ${ }^{\circ} \mathrm{C}$; IR (neat) $\mathrm{cm}^{-1} 3265-2422(\mathrm{br}), 1695$; NMR $\left(\mathrm{CDCl}_{3}, 400 \mathrm{MHz}\right) \delta 2.32$ (s, 3H), $2.44(\mathrm{~s}, 3 \mathrm{H}), 7.23$ (s, 1H), $7.52(\mathrm{~s}, 1 \mathrm{H}) ;{ }^{13} \mathrm{C} \mathrm{NMR}\left(\mathrm{CDCl}_{3}, 100 \mathrm{MHz}\right) \delta 20.6,23.8,120.5,129.8,131.7,135.1,136.8$, $139.8,172.3$. 
2-Bromo-3,5-dimethylbenzylalcohol: Yield 61\%, colorless solid; mp 58-60 ${ }^{\circ} \mathrm{C}$; IR $(\mathrm{KBr}) \mathrm{cm}^{-1}$ 3247, $2921 \mathrm{~cm}^{-1}$; NMR $\left(\mathrm{CDCl}_{3}, 400 \mathrm{MHz}\right) \delta 2.29(\mathrm{~s}, 3 \mathrm{H}), 2.38(\mathrm{~s}, 3 \mathrm{H}), 4.72(\mathrm{~s}, 2 \mathrm{H}), 7.0(\mathrm{~s}, 1 \mathrm{H})$, $7.11(\mathrm{~s}, 1 \mathrm{H})$.

2-Bromo-3,5-dimethylbenzaldehyde: Yield 73\%, white crystalline solid; mp 50-52 ${ }^{\circ} \mathrm{C}$; IR (neat) $\mathrm{cm}^{-1}$ 1690; NMR $\left(\mathrm{CDCl}_{3}, 400 \mathrm{MHz}\right) \delta 2.32(\mathrm{~s}, 3 \mathrm{H}), 2.43(\mathrm{~s}, 3 \mathrm{H}), 7.30(\mathrm{~s}, 1 \mathrm{H}), 7.55$ (s, $1 \mathrm{H}), 10.41(\mathrm{~s}, 1 \mathrm{H}) ;{ }^{13} \mathrm{C} \mathrm{NMR}\left(\mathrm{CDCl}_{3}, 100 \mathrm{MHz}\right) \delta 20.6,22.7,126.4,127.8,133.6,137.3,139.2$, 192.9.

2-Bromo-3,5-dimethylbenzophenone (8a): Yield 83\%, colorless crystalline solid; mp 115-117 ${ }^{\circ} \mathrm{C}$; IR (KBr) cm ${ }^{-1} 1662,1594,1321 ;{ }^{1} \mathrm{H} \mathrm{NMR}\left(\mathrm{CDCl}_{3}, 400 \mathrm{MHz}\right) \delta 2.31(\mathrm{~s}, 3 \mathrm{H}), 2.42(\mathrm{~s}, 3 \mathrm{H})$, $6.94(\mathrm{~s}, 1 \mathrm{H}), 7.17(\mathrm{~s}, 1 \mathrm{H}), 7.45$ (t, $J=7.6 \mathrm{~Hz}, 2 \mathrm{H}), 7.59$ (t, $J=7.6 \mathrm{~Hz}, 1 \mathrm{H})$ ), 7.83 (d, J=8.0 Hz, $2 \mathrm{H}) ;{ }^{13} \mathrm{C} \mathrm{NMR}\left(\mathrm{CDCl}_{3}, 100 \mathrm{MHz}\right) \delta 20.7,22.9,118.0,126.6,128.5,130.2,132.7,133.6,136.2$, 137.1, 138.7, 141.2, 196.6; ESI-MS ${ }^{+} \mathrm{m} / \mathrm{z}$ Calcd for $\mathrm{C}_{15} \mathrm{H}_{13} \mathrm{BrO} 289.0228[\mathrm{M}+\mathrm{H}]$, found 289.0228 .

2-Bromo-3',5'-dimethoxy-3,5-dimethylbenzophenone (8b): Yield 97\%, colorless crystalline solid; mp 83-85 ${ }^{\circ} \mathrm{C}$; IR (KBr) cm ${ }^{-1} 1666,1593 ;{ }^{1} \mathrm{H}$ NMR $\left(\mathrm{CDCl}_{3}, 400 \mathrm{MHz}\right) \delta 2.30$ (s, 3H), 2.41 (s, 3H), 3.81(s, 6H), $6.68(\mathrm{t}, J=2.4 \mathrm{~Hz}, 1 \mathrm{H}), 6.92(\mathrm{~d}, J=1.3 \mathrm{~Hz}, 1 \mathrm{H}), 6.96(\mathrm{~d}, J=2.4 \mathrm{~Hz}, 2 \mathrm{H})$, $7.15(\mathrm{~d}, J=1.3 \mathrm{~Hz}, 1 \mathrm{H}) ;{ }^{13} \mathrm{C} \mathrm{NMR}\left(\mathrm{CDCl}_{3}, 100 \mathrm{MHz}\right) \delta 20.7,22.9,55.6,105.8,108.0,118.0$, 126.5, 132.7, 137.0, 138.2, 138.6, 141.1, 160.8, 196.2; ESI-MS ${ }^{+} \mathrm{m} / \mathrm{z}$ Calcd for $\mathrm{C}_{17} \mathrm{H}_{17} \mathrm{BrO}_{3}$ $349.0439[\mathrm{M}+\mathrm{H}]$, found 349.0439 .

\section{General Procedure for the Photolysis of Ketones}

A 2.5-4.5 $\mathrm{mM}$ solution of the 2-bromobenzophenone derivative in dry acetonitrile was taken in a pyrex tube, purged with $\mathrm{N}_{2}$ gas for $30 \mathrm{~min}$, and irradiated in a Luzchem photoreactor fitted with $\lambda \approx 350 \mathrm{~nm}$ lamps. Depending upon the substrate, the colorless solutions of the ketones turned into yellow or orange or red to reddish brown color within $1 \mathrm{~h}$ of photoirradiation. The progress of the reaction in each case was monitored by GC and TLC analysis. After 
photolysis, the solvent was removed in vacuo and the residue was subjected to a careful silica-gel column chromatography to isolate the photoproducts, viz., fluorenone derivative and dehaloginated benzophenone. All the fluorenone derivatives were characterized by spectroscopic data. All the dehalogenated ketones are reported in the literature, and they were characterized by comparison of their ${ }^{1} \mathrm{H}$ NMR spectral data with the literature data.

3-Benzoyl-2-bromo-1,4-dimethylfluoren-9-one (2-FI): Yield 70\%, yellow crystalline solid; mp 223-225 ${ }^{\circ} \mathrm{C}$; IR (KBr) cm ${ }^{-1} 1705,1671 ;{ }^{1} \mathrm{H} \mathrm{NMR}\left(\mathrm{CDCl}_{3}, 400 \mathrm{MHz}\right) \delta 2.39$ (s, 3H), 2.76 (s, $3 \mathrm{H}), 7.36(\mathrm{t}, J=7.6 \mathrm{~Hz}, 1 \mathrm{H}), 7.42-7.57(\mathrm{~m}, 3 \mathrm{H}), 7.64(\mathrm{t}, J=7.6 \mathrm{~Hz}, 2 \mathrm{H}), 7.73(\mathrm{~d}, J=7.3 \mathrm{~Hz}$, $1 \mathrm{H}), 7.90(\mathrm{~d}, J=7.3 \mathrm{~Hz}, 2 \mathrm{H}) ;{ }^{13} \mathrm{C} \mathrm{NMR}\left(\mathrm{CDCl}_{3}, 100 \mathrm{MHz}\right) \delta 16.4,17.4,123.6,123.7,124.4$, 129.0, 129.1, 129.5, 132.1, 134.3, 134.4, 134.8, 135.6, 137.7, 142.5, 143.2, 146.8, 193.8, 196.4; ESI-MS ${ }^{+} \mathrm{m} / \mathrm{z}$ Calcd for $\mathrm{C}_{22} \mathrm{H}_{16} \mathrm{BrO}_{2} 391.0333[\mathrm{M}+\mathrm{H}]$, found 391.0346 .

3-Methoxyfluoren-9-one (3b-Fl or 4a-Fl) ${ }^{7}$ : Yield 48\%, lemon-yellow crystalline powder; $\mathrm{mp}$ 94-96 ${ }^{\circ} \mathrm{C}$ ( lit. $\left.99{ }^{\circ} \mathrm{C}\right)$; IR (KBr) cm ${ }^{-1} 1702,1596 ;{ }^{1} \mathrm{H}$ NMR $\left(\mathrm{CDCl}_{3}, 400 \mathrm{MHz}\right) \delta 3.90$ (s, 3H), $6.73\left(\mathrm{dd}, J_{1}=8.2 \mathrm{~Hz}, J_{2}=2.2 \mathrm{~Hz}, 1 \mathrm{H}\right), 7.01(\mathrm{~d}, J=2.2 \mathrm{~Hz}, 1 \mathrm{H}), 7.27-7.7 .31(\mathrm{~m}, 1 \mathrm{H}), 7.42-7.49$ (m, 2H), 7.61(d, $J=8.2 \mathrm{~Hz}, 1 \mathrm{H}), 7.62(\mathrm{~d}, J=7.3 \mathrm{~Hz}, 1 \mathrm{H}) ;{ }^{13} \mathrm{C} \mathrm{NMR}\left(\mathrm{CDCl}_{3}, 100 \mathrm{MHz}\right) \delta 55.7$, 107.0, 112.9, 120.1, 123.8, 126.2, 127.1, 128.4, 129.3, 134.1, 135.3, 143.3, 147.0, 165.3, 192.5.

4-Methoxybenzophenone (3b-Bp) $)^{8}$ : Yield $39 \%$, colorless solid; mp $58-60{ }^{\circ} \mathrm{C}$ (lit. $62-64{ }^{\circ} \mathrm{C}$ ); IR $(\mathrm{KBr}) \mathrm{cm}^{-1} 1653,1600 ;{ }^{1} \mathrm{H} \mathrm{NMR}\left(\mathrm{CDCl}_{3}, 400 \mathrm{MHz}\right) \delta 3.81(\mathrm{~s}, 3 \mathrm{H}), 6.88(\mathrm{~d}, J=8.8 \mathrm{~Hz}, 2 \mathrm{H})$, $7.40(\mathrm{t}, J=7.8 \mathrm{~Hz}, 2 \mathrm{H}), 7.49(\mathrm{t}, J=7.1 \mathrm{~Hz}, 1 \mathrm{H}), 7.68(\mathrm{~d}, J=7.8 \mathrm{~Hz}, 2 \mathrm{H}), 7.61(\mathrm{~d}, J=8.8 \mathrm{~Hz}$, $2 \mathrm{H})$.

3-Trifluoromethylfluoren-9-one (3c-FI): Yellowish green crystalline solid; mp 133-135 ${ }^{\circ} \mathrm{C}$; IR $(\mathrm{KBr}) \mathrm{cm}^{-1} 1714 ;{ }^{1} \mathrm{H} \mathrm{NMR}\left(\mathrm{CDCl}_{3}, 400 \mathrm{MHz}\right) \delta 7.38(\mathrm{t}, J=7.3 \mathrm{~Hz}, 1 \mathrm{H}), 7.54-7.61(\mathrm{~m}, 3 \mathrm{H}), 7.72$ (d, $J=7.3 \mathrm{~Hz}, 1 \mathrm{H}), 7.75(\mathrm{~s}, 1 \mathrm{H}), 7.76(\mathrm{~d}, J=7.3 \mathrm{~Hz}, 1 \mathrm{H}) ;{ }^{13} \mathrm{C} \mathrm{NMR}\left(\mathrm{CDCl}_{3}, 100 \mathrm{MHz}\right) \delta 117.2$, $120.8,124.4,124.8,126.3,128.5,130.0,130.1,134.0,135.3,136.7,143.2,144.9,192.5$; ESI$\mathrm{MS}^{+} \mathrm{m} / \mathrm{z}$ Calcd for $\mathrm{C}_{14} \mathrm{H}_{8} \mathrm{~F}_{3} \mathrm{O} 249.0527[\mathrm{M}+\mathrm{H}]$, found 249.0524 . 
4-Trifluoromethylbenzophenone (3c-Bp) ${ }^{8}$ : Colorless solid; mp 112-114 ${ }^{\circ} \mathrm{C}$ (lit. $115{ }^{\circ} \mathrm{C}$ ); IR $(\mathrm{KBr}) \mathrm{cm}^{-1} 1652 ;{ }^{1} \mathrm{H} \mathrm{NMR}\left(\mathrm{CDCl}_{3}, 400 \mathrm{MHz}\right) \delta 7.51(\mathrm{t}, J=7.6 \mathrm{~Hz}, 2 \mathrm{H}), 7.63(\mathrm{t}, J=7.6 \mathrm{~Hz}, 2 \mathrm{H})$, $7.75(\mathrm{~d}, J=8.5 \mathrm{~Hz}, 1 \mathrm{H}), 8.5(\mathrm{~d}, J=8.0 \mathrm{~Hz}, 2 \mathrm{H}), 7.61(\mathrm{~d}, J=8.5 \mathrm{~Hz}, 2 \mathrm{H})$.

2-Methoxyfluoren-9-one (3d-FI) ${ }^{7}$ : Yield 80\%, yellow crystalline powder; mp 72-74 ${ }^{\circ} \mathrm{C}$; IR (neat) $\mathrm{cm}^{-1} 1712,1602 ;{ }^{1} \mathrm{H}$ NMR $\left(\mathrm{CDCl}_{3}, 400 \mathrm{MHz}\right) 3.85(\mathrm{~s}, 3 \mathrm{H}), 6.96-6.98(\mathrm{~m}, 1 \mathrm{H}), 7.17-7.21$

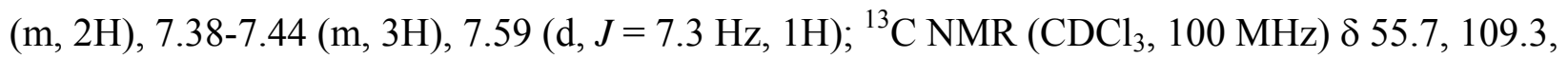
$119.5,120.3,121.3,124.3,127.9,134.3,134.8,135.9,137.0,144.8,160.8,193.9$.

3-Methoxybenzophenone (3d-Bp) ${ }^{8}$ : Colorless oil; IR $(\mathrm{KBr}) \mathrm{cm}^{-1} 1659,1591 ;{ }^{1} \mathrm{H} \mathrm{NMR}\left(\mathrm{CDCl}_{3}\right.$, $400 \mathrm{MHz}) \delta 3.90(\mathrm{~s}, 3 \mathrm{H}), 7.12-7.18(\mathrm{~m}, 1 \mathrm{H}), 7.33-7.40(\mathrm{~m}, 3 \mathrm{H}), 7.48(\mathrm{t}, J=7.3 \mathrm{~Hz}, 2 \mathrm{H}), 7.59(\mathrm{t}$, $J=7.3 \mathrm{~Hz}, 1 \mathrm{H}), 7.81(\mathrm{~d}, J=7.1 \mathrm{~Hz}, 2 \mathrm{H})$.

2,4-Dimethoxyfluoren-9-one (3e-Fl): Yield 80\%, orange crystalline powder; mp 142-144 ${ }^{\circ} \mathrm{C}$; IR $(\mathrm{KBr}) \mathrm{cm}^{-1} 1713,1604 ;{ }^{1} \mathrm{H} \mathrm{NMR}\left(\mathrm{CDCl}_{3}, 400 \mathrm{MHz}\right) \delta 3.85(\mathrm{~s}, 3 \mathrm{H}), 3.93(\mathrm{~s}, 3 \mathrm{H}), 6.56(\mathrm{~d}, J=2.2$ $\mathrm{Hz}, 1 \mathrm{H}), 6.85(\mathrm{~d}, J=2.2 \mathrm{~Hz}, 1 \mathrm{H}), 7.13\left(\mathrm{td}, J_{1}=7.3 \mathrm{~Hz}, J_{2}=1.0 \mathrm{~Hz}, 1 \mathrm{H}\right), 7.39$ (td, $J_{1}=7.6 \mathrm{~Hz}$, $\left.J_{2}=1.2 \mathrm{~Hz}, 1 \mathrm{H}\right), 7.56(\mathrm{~d}, J=7.3 \mathrm{~Hz}, 1 \mathrm{H}), 7.67(\mathrm{~d}, J=7.6 \mathrm{~Hz}, 1 \mathrm{H}) ;{ }^{13} \mathrm{C} \mathrm{NMR}\left(\mathrm{CDCl}_{3}, 100 \mathrm{MHz}\right)$ $\delta 55.6,55.8,100.5,104.8,123.1,123.9,124.6,126.9,133.5,134.9,136.6,144.3,156.2,162.1$, 194.2; ESI-MS ${ }^{+} \mathrm{m} / \mathrm{z}$ Calcd for $\mathrm{C}_{15} \mathrm{H}_{13} \mathrm{O}_{3} 241.0864$ [M+H], found 241.0869.

3,5-Dimethoxybenzophenone (3e-Bp) ${ }^{9}$ : Colorless oil; IR $(\mathrm{KBr}) \mathrm{cm}^{-1} 1663,1592$; ${ }^{1} \mathrm{H}$ NMR $\left(\mathrm{CDCl}_{3}, 400 \mathrm{MHz}\right) \delta 3.83(\mathrm{~s}, 6 \mathrm{H}), 6.68(\mathrm{~d}, J=2.2 \mathrm{~Hz}, 1 \mathrm{H}), 6.92(\mathrm{~d}, J=2.2 \mathrm{~Hz}, 2 \mathrm{H}), 7.48(\mathrm{t}, J=$ $8.0 \mathrm{~Hz}, 2 \mathrm{H}), 7.59(\mathrm{t}, J=6.8 \mathrm{~Hz}, 1 \mathrm{H}), 7.81(\mathrm{~d}, J=8.0 \mathrm{~Hz}, 2 \mathrm{H})$.

2,4-Dimethylfluoren-9-one (3f-Fl or 8a-Fl): Yields are 67\% and 80\% for photolysis of ketones 3f and 8a respectively, chrome yellow crystalline powder; mp 130-132 ${ }^{\circ} \mathrm{C}$; IR (KBr) $\mathrm{cm}^{-1} 1707$, 1606; ${ }^{1} \mathrm{H} \mathrm{NMR}\left(\mathrm{CDCl}_{3}, 400 \mathrm{MHz}\right) \delta 2.32$ (s, 3H), 2.54 (s, 3H), 7.06 (s, 1H), 7.23 (d, J= 7.3 Hz, $1 \mathrm{H}), 7.34(\mathrm{~s}, 1 \mathrm{H}), 7.46\left(\mathrm{td}, J_{1}=7.6 \mathrm{~Hz}, J_{2}=1.2 \mathrm{~Hz}, 1 \mathrm{H}\right), 7.57(\mathrm{~d}, J=7.6 \mathrm{~Hz}, 1 \mathrm{H}), 7.64(\mathrm{~d}, J=$ $7.3 \mathrm{~Hz}, 1 \mathrm{H}) ;{ }^{13} \mathrm{C} \mathrm{NMR}\left(\mathrm{CDCl}_{3}, 100 \mathrm{MHz}\right) \delta 20.0,21.1,122.6,122.9,124.1,127.9,133.3,134.5$, 134.6, 134.8, 137.9, 138.9, 139.5, 145.5, 194.5; ESI-MS ${ }^{+} \mathrm{m} / \mathrm{z}$ Calcd for $\mathrm{C}_{15} \mathrm{H}_{13} \mathrm{O} 209.0966$ $[\mathrm{M}+\mathrm{H}]$, found 209.0967. 
3,5'-Dimethybenzophenone (3f-Bp) ${ }^{10}$ : Colorless oil; IR (KBr) $\mathrm{cm}^{-1} 1659,1599 ;{ }^{1} \mathrm{H}$ NMR $\left(\mathrm{CDCl}_{3}, 400 \mathrm{MHz}\right) \delta 2.38(\mathrm{~s}, 6 \mathrm{H}), 7.22(\mathrm{~s}, 1 \mathrm{H}), 7.40(\mathrm{~s}, 2 \mathrm{H}), 7.48(\mathrm{t}, J=7.8 \mathrm{~Hz}, 2 \mathrm{H}), 7.58(\mathrm{t}, J=$ $7.3 \mathrm{~Hz}, 1 \mathrm{H}), 7.80(\mathrm{~d}, J=7.8 \mathrm{~Hz}, 2 \mathrm{H})$.

3,6-Dimethoxyfluoren-9-one (4b-FI) ${ }^{11}$ : Yield 48\%, pale yellow crystalline powder; mp 146$148{ }^{\circ} \mathrm{C}$ (lit. 142-144 ${ }^{\circ} \mathrm{C}$ ); IR (neat) $\mathrm{cm}^{-1} 1691,1612,1595 ;{ }^{1} \mathrm{H}$ NMR $\left(\mathrm{CDCl}_{3}, 400 \mathrm{MHz}\right) \delta 3.91$ (s, $6 \mathrm{H}), 6.75\left(\mathrm{dd}, J_{1}=8.3 \mathrm{~Hz}, J_{2}=2.2 \mathrm{~Hz}, 2 \mathrm{H}\right), 7.00(\mathrm{~d}, J=2.2 \mathrm{~Hz}, 2 \mathrm{H}), 7.59$ (d, $\left.J=8.3 \mathrm{~Hz}, 2 \mathrm{H}\right)$; ${ }^{13} \mathrm{C}$ NMR $\left(\mathrm{CDCl}_{3}, 100 \mathrm{MHz}\right) \delta 55.7,107.0,113.0,125.7,128.3,145.9,165.0,191.4$.

4,4'-Dimethoxybenzophenone (4b-Bp) $)^{12}$ : Colorless solid; mp 144-146 ${ }^{\circ} \mathrm{C}$ (lit. $140-142^{\circ} \mathrm{C}$ ); IR $(\mathrm{KBr}) \mathrm{cm}^{-1} 1637,1601 ;{ }^{1} \mathrm{H} \mathrm{NMR}\left(\mathrm{CDCl}_{3}, 400 \mathrm{MHz}\right) \delta 3.89$ (s, 6H), 6.96 (d, $\left.J=8.8 \mathrm{~Hz}, 4 \mathrm{H}\right), 7.78$ (d, $J=8.8 \mathrm{~Hz}, 4 \mathrm{H})$.

2,6-Dimethoxyfluoren-9-one (4c-Fl): Yellow crystalline powder; mp 120-122 ${ }^{\circ} \mathrm{C}$; $\mathrm{IR}(\mathrm{KBr}) \mathrm{cm}^{-}$ ${ }^{1} 1707,1611 ;{ }^{1} \mathrm{H}$ NMR $\left(\mathrm{CDCl}_{3}, 400 \mathrm{MHz}\right) \delta 3.85$ (s, 3H), 3.89 (s, 3H), $6.64\left(\mathrm{dd}, J_{1}=8.2 \mathrm{~Hz}, J_{2}\right.$ $=2.2 \mathrm{~Hz}, 1 \mathrm{H}), 6.91(\mathrm{~d}, J=2.2 \mathrm{~Hz}, 1 \mathrm{H}), 6.94\left(\mathrm{dd}, J_{1}=8.1 \mathrm{~Hz}, J_{2}=2.4 \mathrm{~Hz}, 1 \mathrm{H}\right), 7.17(\mathrm{~d}, J=2.4$ $\mathrm{Hz}, 1 \mathrm{H}), 7.36(\mathrm{~d}, J=8.3 \mathrm{~Hz}, 1 \mathrm{H}), 7.56(\mathrm{~d}, J=8.3 \mathrm{~Hz}, 1 \mathrm{H}) ;{ }^{13} \mathrm{C} \mathrm{NMR}\left(\mathrm{CDCl}_{3}, 100 \mathrm{MHz}\right) \delta 55.7$ (x2), 106.5, 109.1, 111.6, 119.6, 121.2, 126.3, 127.3, 135.8, 137.2, 147.5, 161.1, 165.6, 192.4; ESI-MS ${ }^{+} \mathrm{m} / \mathrm{z}$ Calcd for $\mathrm{C}_{15} \mathrm{H}_{13} \mathrm{O}_{3} 241.0865[\mathrm{M}+\mathrm{H}]$, found 241.0864 .

3,5'-Dimethoxybenzophenone (4c-Bp) ${ }^{13}$ : Colorless oil; IR (KBr) $\mathrm{cm}^{-1} 1637,1601 ;{ }^{1} \mathrm{H}$ NMR $\left(\mathrm{CDCl}_{3}, 400 \mathrm{MHz}\right) \delta 3.86(\mathrm{~s}, 3 \mathrm{H}), 3.89(\mathrm{~s}, 3 \mathrm{H}), 6.96(\mathrm{~d}, \mathrm{~J}=8.8 \mathrm{~Hz}, 2 \mathrm{H}), 7.09-7.12(\mathrm{~m}, 1 \mathrm{H}), 7.24-$ $7.33(\mathrm{~m}, 2 \mathrm{H}), 7.37(\mathrm{t}, J=8.0 \mathrm{~Hz}, 1 \mathrm{H}), 7.83(\mathrm{~d}, J=8.8 \mathrm{~Hz}, 2 \mathrm{H})$.

2,4,6-Trimethoxyfluoren-9-one (4d-FI) ${ }^{14}$ : Yield 92\%, golden-yellow crystalline powder; mp 186-188 ${ }^{\circ} \mathrm{C}$ (lit. 190-192 ${ }^{\circ} \mathrm{C}$ ); IR (neat) $\mathrm{cm}^{-1} 1704,1605 ;{ }^{1} \mathrm{H}$ NMR $\left(\mathrm{CDCl}_{3}, 400 \mathrm{MHz}\right) \delta 3.85$ (s, $3 \mathrm{H}), 3.89(\mathrm{~s}, 3 \mathrm{H}), 3.92(\mathrm{~s}, 3 \mathrm{H}), 6.54(\mathrm{~d}, J=1.9 \mathrm{~Hz}, 1 \mathrm{H}), 6.58\left(\mathrm{dd}, J_{1}=8.1 \mathrm{~Hz}, J_{2}=2.2 \mathrm{~Hz}, 1 \mathrm{H}\right)$, $6.83(\mathrm{~d}, J=1.9 \mathrm{~Hz}, 1 \mathrm{H}), 7.22(\mathrm{~d}, J=2.2 \mathrm{~Hz}, 1 \mathrm{H}), 7.53(\mathrm{~d}, J=8.1 \mathrm{~Hz}, 1 \mathrm{H}) ;{ }^{13} \mathrm{C}$ NMR $\left(\mathrm{CDCl}_{3}\right.$, $100 \mathrm{MHz}) \delta 55.58,55.64,55.8,100.4,104.3,110.3,123.3,125.9,126.6,138.0,146.8,156.1$, $162.4,165.5,192.7$. 
2,4,7-Trimethoxyfluoren-9-one (5-FI): Yield 95\%, red crystalline powder; mp 150-152 ${ }^{\circ} \mathrm{C}$; IR (neat) $\mathrm{cm}^{-1} 1714,1607 ;{ }^{1} \mathrm{H}$ NMR $\left(\mathrm{CDCl}_{3}, 400 \mathrm{MHz}\right) \delta 3.82(\mathrm{~s}, 3 \mathrm{H}), 3.83(\mathrm{~s}, 3 \mathrm{H}), 3.90(\mathrm{~s}, 3 \mathrm{H})$, $6.53(\mathrm{~d}, J=1.9 \mathrm{~Hz}, 1 \mathrm{H}), 6.80(\mathrm{~d}, J=1.9 \mathrm{~Hz}, 1 \mathrm{H}), 6.89\left(\mathrm{dd}, J_{1}=8.1 \mathrm{~Hz}, J_{2}=2.4 \mathrm{~Hz}, 1 \mathrm{H}\right), 7.13$ $(\mathrm{d}, J=2.4 \mathrm{~Hz}, 1 \mathrm{H}), 7.52(\mathrm{~d}, J=8.1 \mathrm{~Hz}, 1 \mathrm{H}) ;{ }^{13} \mathrm{C} \mathrm{NMR}\left(\mathrm{CDCl}_{3}, 100 \mathrm{MHz}\right) \delta 55.56,55.62,55.8$, 100.8, 105.1, 109.7, 119.9, 123.9, 125.3, 135.2, 136.7, 136.9, 155.5, 159.2, 161.3, 194.1; ESI$\mathrm{MS}^{+} \mathrm{m} / \mathrm{z}$ Calcd for $\mathrm{C}_{16} \mathrm{H}_{15} \mathrm{O}_{4} 271.0970[\mathrm{M}+\mathrm{H}]$, found 271.0977 .

2,3,5,6-Tetramethoxyfluoren-9-one (6b-Fl): Yield 75\%, reddish orange crystalline powder; $\mathrm{mp}$ 170-172 ${ }^{\circ} \mathrm{C}$; IR (neat) $\mathrm{cm}^{-1} 1704,1605 ;{ }^{1} \mathrm{H}$ NMR $\left(\mathrm{CDCl}_{3}, 400 \mathrm{MHz}\right) \delta 3.84(\mathrm{~s}, 3 \mathrm{H}), 3.89$ (s, 3H), 3.92 (s, 3H), 3.99 (s, 3H), 6.51 (d, J=1.9 Hz, 1H), 6.79 (d, J = $1.9 \mathrm{~Hz}, 1 \mathrm{H}), 7.14$ (s, 1H), 7.21 (s, $1 \mathrm{H}) ;{ }^{13} \mathrm{C}$ NMR $\left(\mathrm{CDCl}_{3}, 100 \mathrm{MHz}\right) \delta 55.6,55.8,56.1,56.2,101.0,104.3,106.6,107.4,123.5$, 125.9, 137.4, 139.9, 147.9, 154.4, 155.1, 161.7, 193.3; ESI-MS ${ }^{+} \mathrm{m} / \mathrm{z}$ Calcd for $\mathrm{C}_{17} \mathrm{H}_{17} \mathrm{O}_{5}$ $301.1076[\mathrm{M}+\mathrm{H}]$, found 301.1074 .

2,4,5,7-Tetramethoxyfluoren-9-one (7b-FI): Yield 94\%, reddish brown crystalline powder; mp 139-141 ${ }^{\circ} \mathrm{C}$; IR ( $\left.\mathrm{KBr}\right) \mathrm{cm}^{-1} 1711,1608 ;{ }^{1} \mathrm{H}$ NMR $\left(\mathrm{CDCl}_{3}, 400 \mathrm{MHz}\right) \delta 3.83(\mathrm{~s}, 6 \mathrm{H}), 3.88(\mathrm{~s}, 6 \mathrm{H})$, $6.56(\mathrm{~d}, J=2.2 \mathrm{~Hz}, 2 \mathrm{H}), 6.86(\mathrm{~d}, J=2.2 \mathrm{~Hz}, 2 \mathrm{H}) ;{ }^{13} \mathrm{C} \mathrm{NMR}\left(\mathrm{CDCl}_{3}, 100 \mathrm{MHz}\right) \delta 55.7,56.9$, 102.0, 106.2, 107.1, 108.0, 125.0, 136.9, 154.8, 160.9, 193.9; ESI-MS ${ }^{+} \mathrm{m} / \mathrm{z}$ Calcd for $\mathrm{C}_{17} \mathrm{H}_{17} \mathrm{O}_{5}$ $301.1076[\mathrm{M}+\mathrm{H}]$, found 301.1078 .

2,4-Dimethoxy-5,7-dimethylfluoren-9-one (8b-Fl): Yield 98\%, orange crystalline powder; $\mathrm{mp}$ 126-128 ${ }^{\circ} \mathrm{C}$; IR (KBr) cm ${ }^{-1} 11713,1615 ;{ }^{1} \mathrm{H}$ NMR $\left(\mathrm{CDCl}_{3}, 400 \mathrm{MHz}\right) \delta 2.27$ (s, 3H), $2.58(\mathrm{~s}$, $3 \mathrm{H}), 3.84(\mathrm{~s}, 3 \mathrm{H}), 3.85$ (s, 3H), $6.53(\mathrm{~d}, J=2.2 \mathrm{~Hz}, 1 \mathrm{H}), 6.86(\mathrm{~d}, J=2.2 \mathrm{~Hz}, 1 \mathrm{H}), 7.01(\mathrm{~s}, 1 \mathrm{H})$, $7.26(\mathrm{~s}, 1 \mathrm{H}) ;{ }^{13} \mathrm{C} \mathrm{NMR}\left(\mathrm{CDCl}_{3}, 100 \mathrm{MHz}\right) \delta 20.6,23.0,55.2,55.7,100.8,105.4,122.6,125.9$, 133.2, 134.9, 136.9, 137.6, 139.4, 140.3, 154.7, 161.5, 194.5; ESI-MS ${ }^{+} \mathrm{m} / \mathrm{z}$ Calcd for $\mathrm{C}_{17} \mathrm{H}_{17} \mathrm{O}_{3}$ $269.1178[\mathrm{M}+\mathrm{H}]$, found 269.1179 .

2,4-Dimethoxy-6-trifluoromethylfluoren-9-one (8c-FI): Yield 35\%, cannery yellow crystalline powder; mp $163-165{ }^{\circ} \mathrm{C}$; IR (neat) $\mathrm{cm}^{-1} 1718 ;{ }^{1} \mathrm{H} \mathrm{NMR}\left(\mathrm{CDCl}_{3}, 400 \mathrm{MHz}\right) \delta 2.36$ (s, 3H), 2.58 (s, 3H), 7.13 (s, 1H), 7.38 (s, 1H), 7.53 (d, $J=7.6 \mathrm{~Hz}, 1 \mathrm{H}), 7.73$ (d, $J=7.6 \mathrm{~Hz}, 1 \mathrm{H})$, $7.76(\mathrm{~s}, 1 \mathrm{H}) ;{ }^{13} \mathrm{C} \mathrm{NMR}\left(\mathrm{CDCl}_{3}, 100 \mathrm{MHz}\right) \delta 20.0,21.1,119.3,119.4,123.1,124.1,125.20$, 
125.24, 133.9, 134.7, 137.1, 138.4, 140.0, 145.9, 193.0; ESI-MS ${ }^{+} \mathrm{m} / \mathrm{z}$ Calcd for $\mathrm{C}_{16} \mathrm{H}_{12} \mathrm{~F}_{3} \mathrm{O}$ $277.0840[\mathrm{M}+\mathrm{H}]$, found 277.0848 .

3,5-Dimethoxy-4'-trifluoromethylbenzophenone (8c-Bp): Yield 8\%, colorless oil; IR (neat) $\mathrm{cm}^{-1} 1654 ;{ }^{1} \mathrm{H}$ NMR $\left(\mathrm{CDCl}_{3}, 400 \mathrm{MHz}\right) \delta 2.31$ (s, 6H), 7.18 (s, 1H), $7.32(\mathrm{~s}, 2 \mathrm{H}), 7.67$ (d, J = 8.0 $\mathrm{Hz}, 2 \mathrm{H}), 7.80(\mathrm{~d}, J=8.0 \mathrm{~Hz}, 2 \mathrm{H}) ;{ }^{13} \mathrm{C} \mathrm{NMR}\left(\mathrm{CDCl}_{3}, 100 \mathrm{MHz}\right) \delta 21.2,125.2,125.3,127.8$, 130.1, 130.3, 134.7, 136.9, 138.2, 141.1, 195.9.

\section{References:}

(1) Wagner, P. J.; Sedon, J. H.; Gudmundsdottir, A. J. Am. Chem. Soc. 1996, 118, 746.

(2) Davila, A. C.; Herndon, J. W. J. Org. Chem. 2006, 71, 6682.

(3) Rosillo, M.; Domínguez, G.; Casarrubios, L.; Amador, U.; -Castells, J. P. J. Org. Chem. 2004, 69, 2084.

(4) Sinhababu, A. K.; Borchardt, R. T. J. Org. Chem. 1983, 48, 2356.

(5) Inamoto, K.; Katsuno, M.; Yoshino, T.; Arai, Y.; Hiroya, K.; Sakamoto, T. Tetrahedron 2007, 63, 2695.

(6) Moorthy, J. N.; Venkatakrishnan, P.; Mal, P.; Venugopalan, P. J. Org. Chem. 2003, 68, 327.

(7) Campo, M. A.; Larock, R. C. Org. Lett. 2000, 2, 3675.

(8) Wang, D.; Zhang, Z. Org. Lett. 2003, 5, 4645.

(9) Frenette, R.; Monette, M.; Bernstein, M. A.; Young, R. N.; Verhoeven, T. R. J. Org. Chem. 1991, 56, 3083.

(10) Wang, J.; Nayak, B. R.; Creed, D.; Hoyle, C. E.; Mathias, L. J. Polymer 2005, 46, 6897.

(11) Chuang, C.; Lapin, S. C.; Schrock, A. K.; Schuster, G. B. J. Am. Chem. Soc. 1985, 107, 4238.

(12) Smith, P. A. S.; Messing, C. R. J. Org. Chem. 1988, 53, 2959.

(13) Klemn, L. H.; Mann, R.; Lind, C. D. J. Org. Chem. 1958, 23, 349.

(14) Sargent, M. V. J. Chem. Soc., Perkin Trans. 1 1987, 2553. 

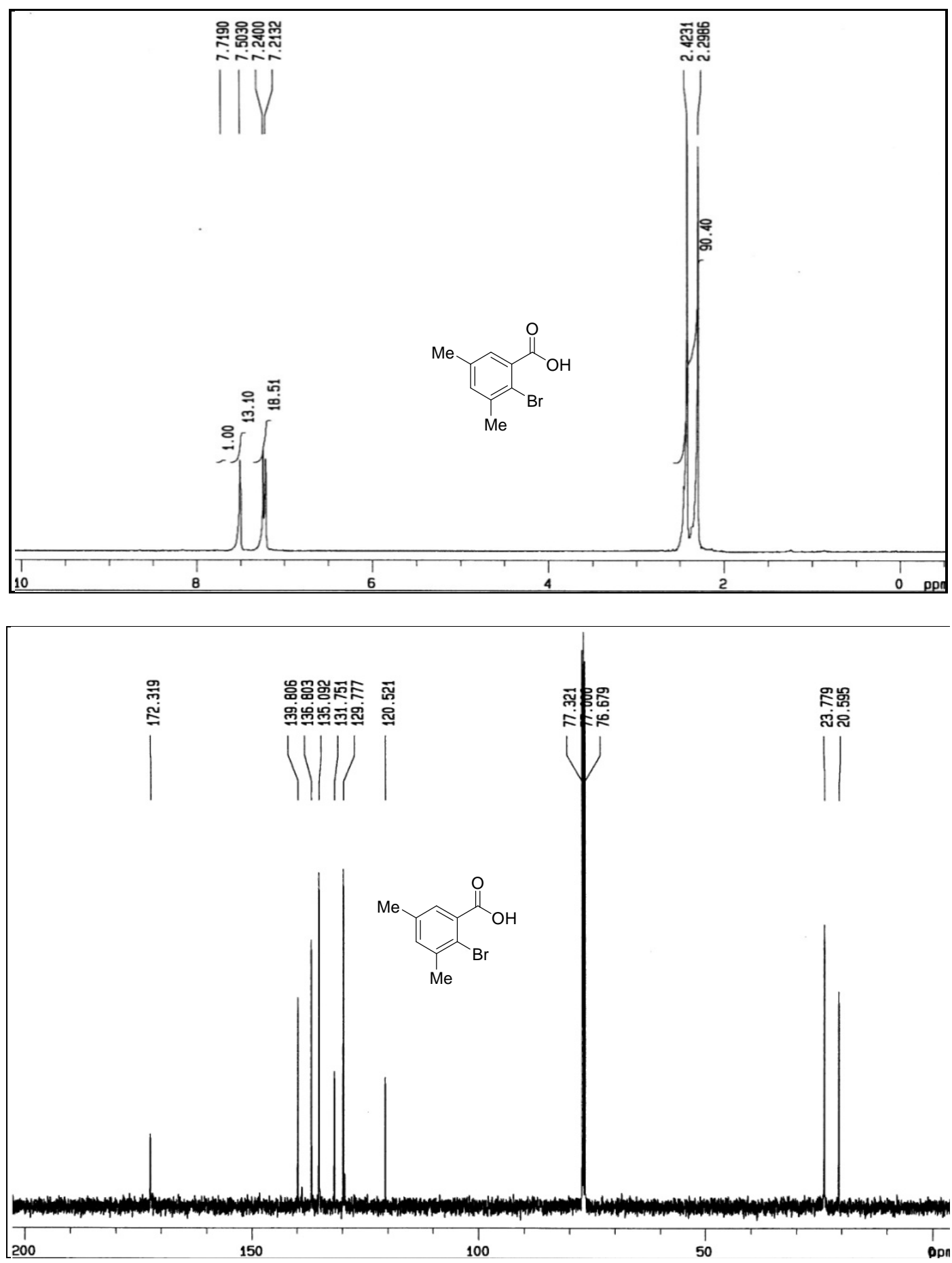

Figure S1. ${ }^{1} \mathrm{H}$ and ${ }^{13} \mathrm{C}$ NMR spectra of 2-bromo-3,5-dimethylbenzoic acid. 


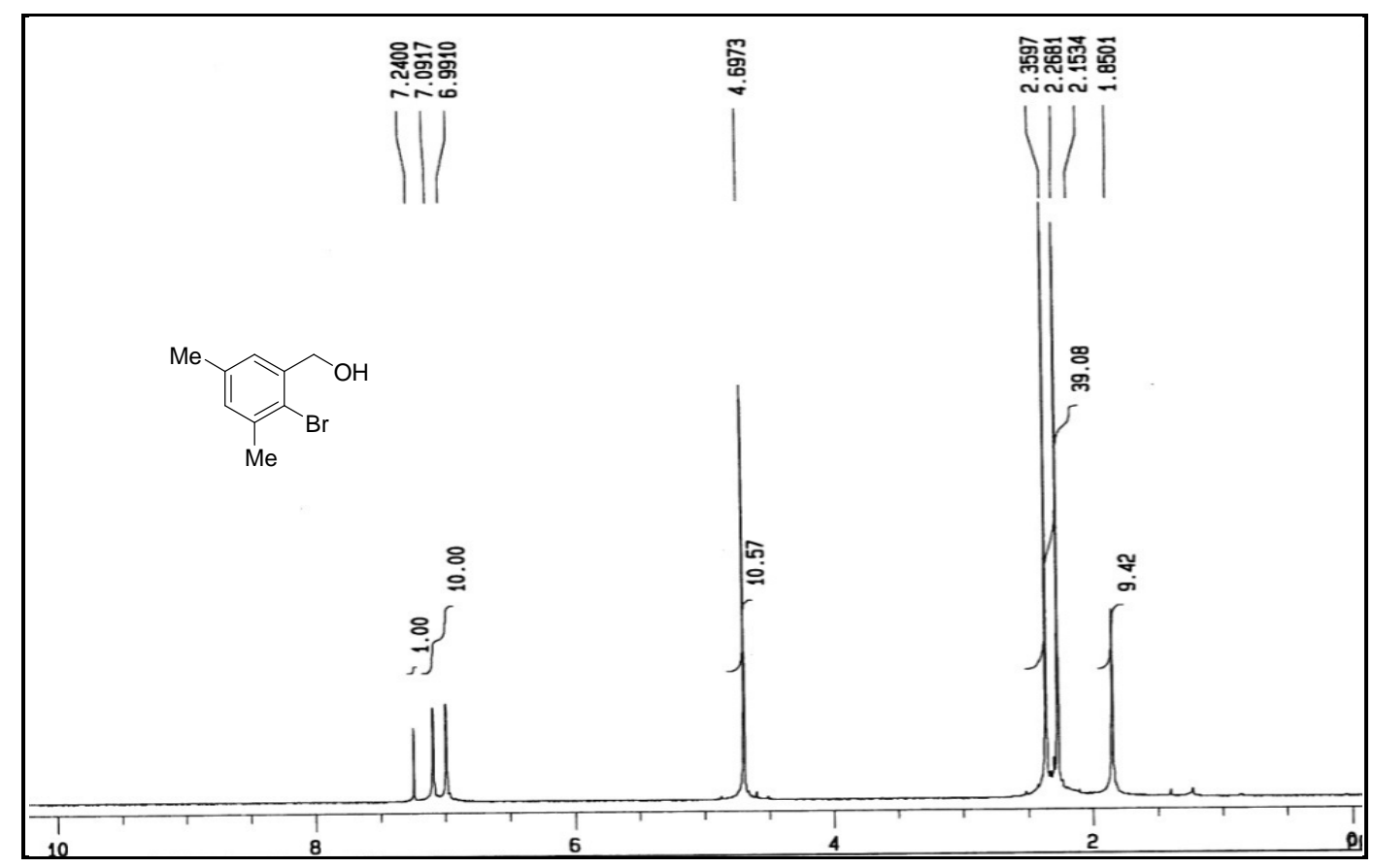

Figure S2. ${ }^{1}$ H NMR spectrum of 2-bromo-3,5-dimethylbenzylalcohol. 

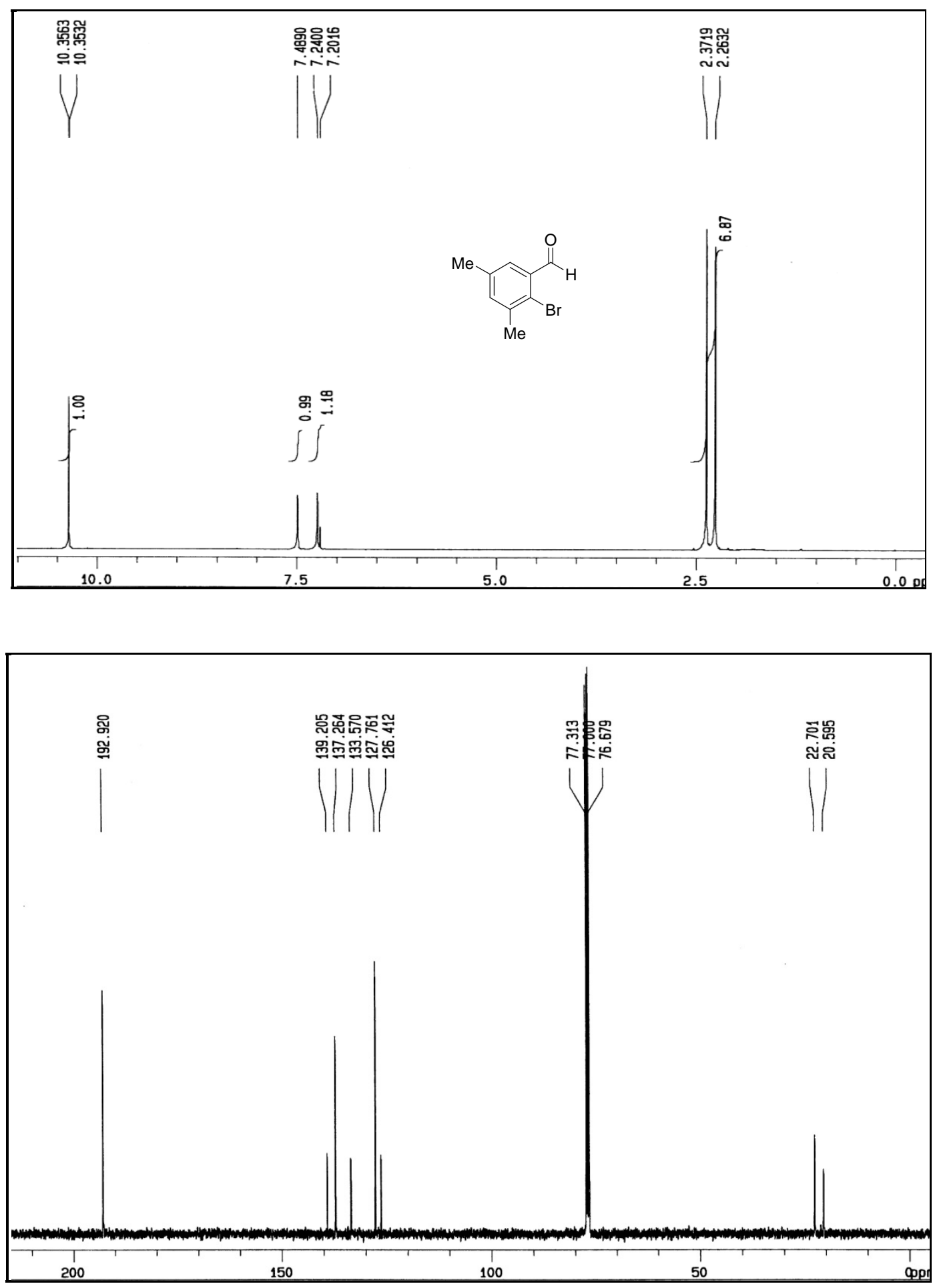

Figure S3. ${ }^{1} \mathrm{H}$ and ${ }^{13} \mathrm{C}$ NMR spectra of 2-bromo-3,5-dimethylbenzaldehyde. 

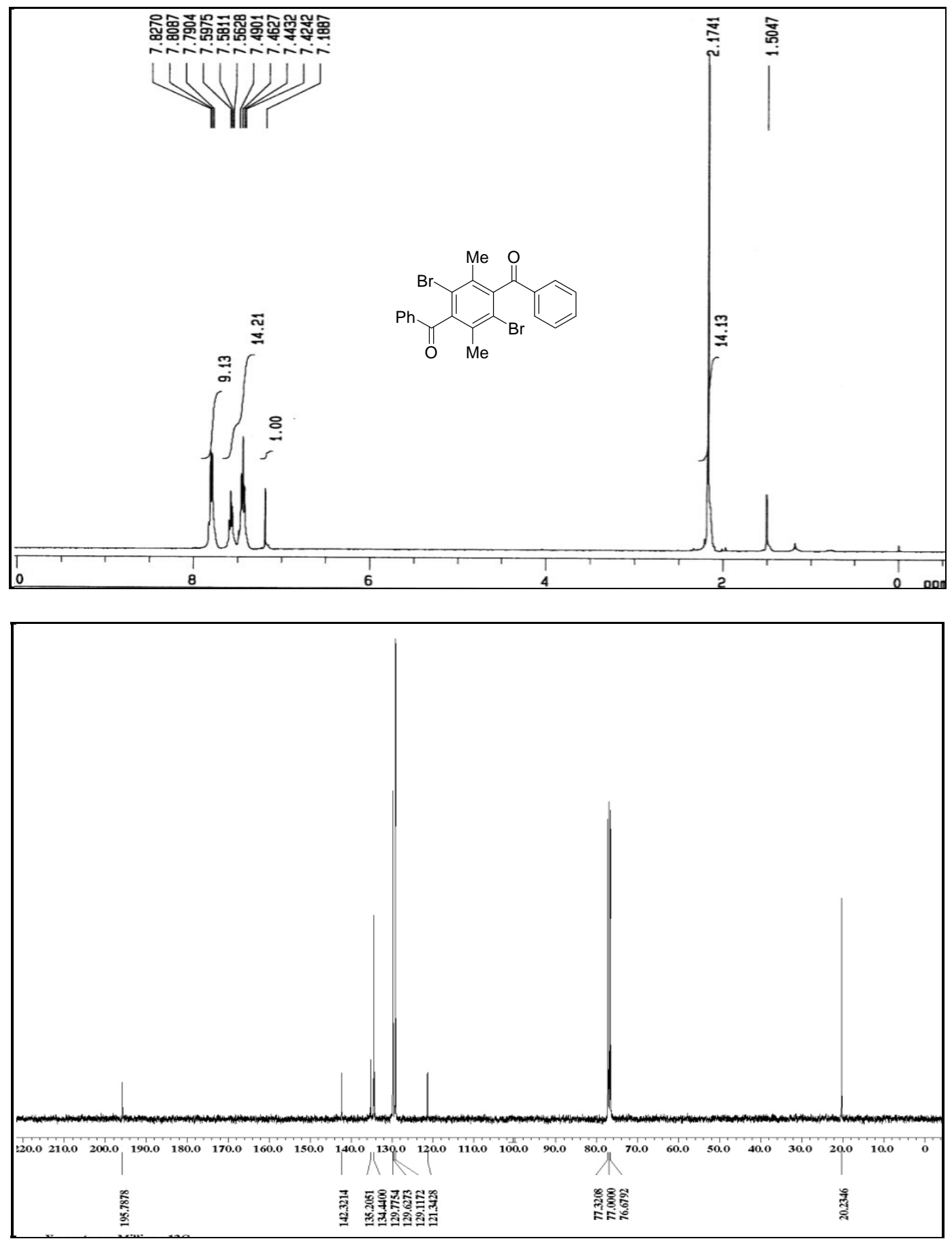

Figure S4. ${ }^{1} \mathrm{H}$ and ${ }^{13} \mathrm{C}$ NMR spectra of 2,5-dibromo-4-benzoyl-3,6-dimethylbenzophenone 2 

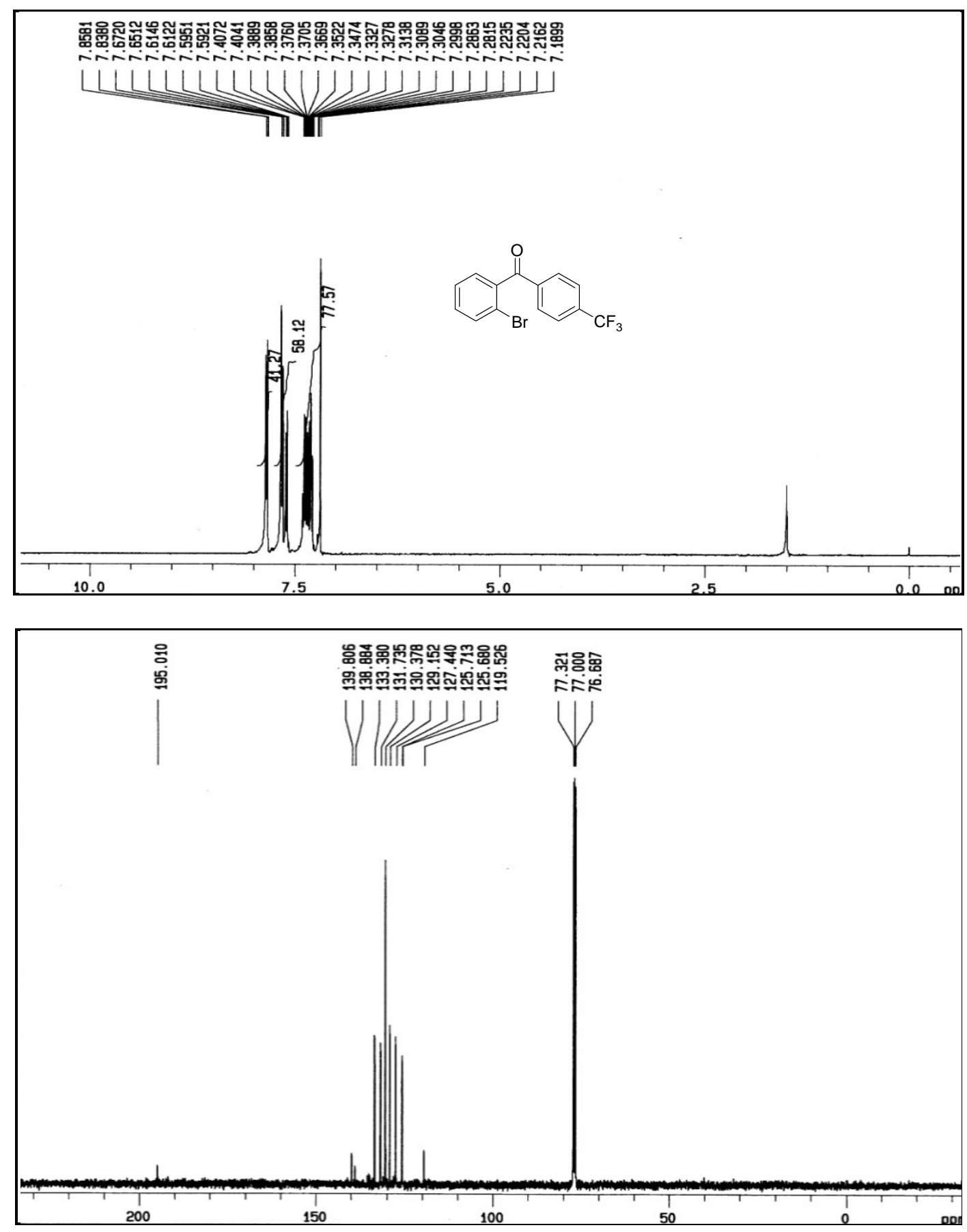

Figure S5. ${ }^{1} \mathrm{H}$ and ${ }^{13} \mathrm{C}$ NMR spectra of 2-bromo-4'-trifluoromethylbenzophenone 3c. 

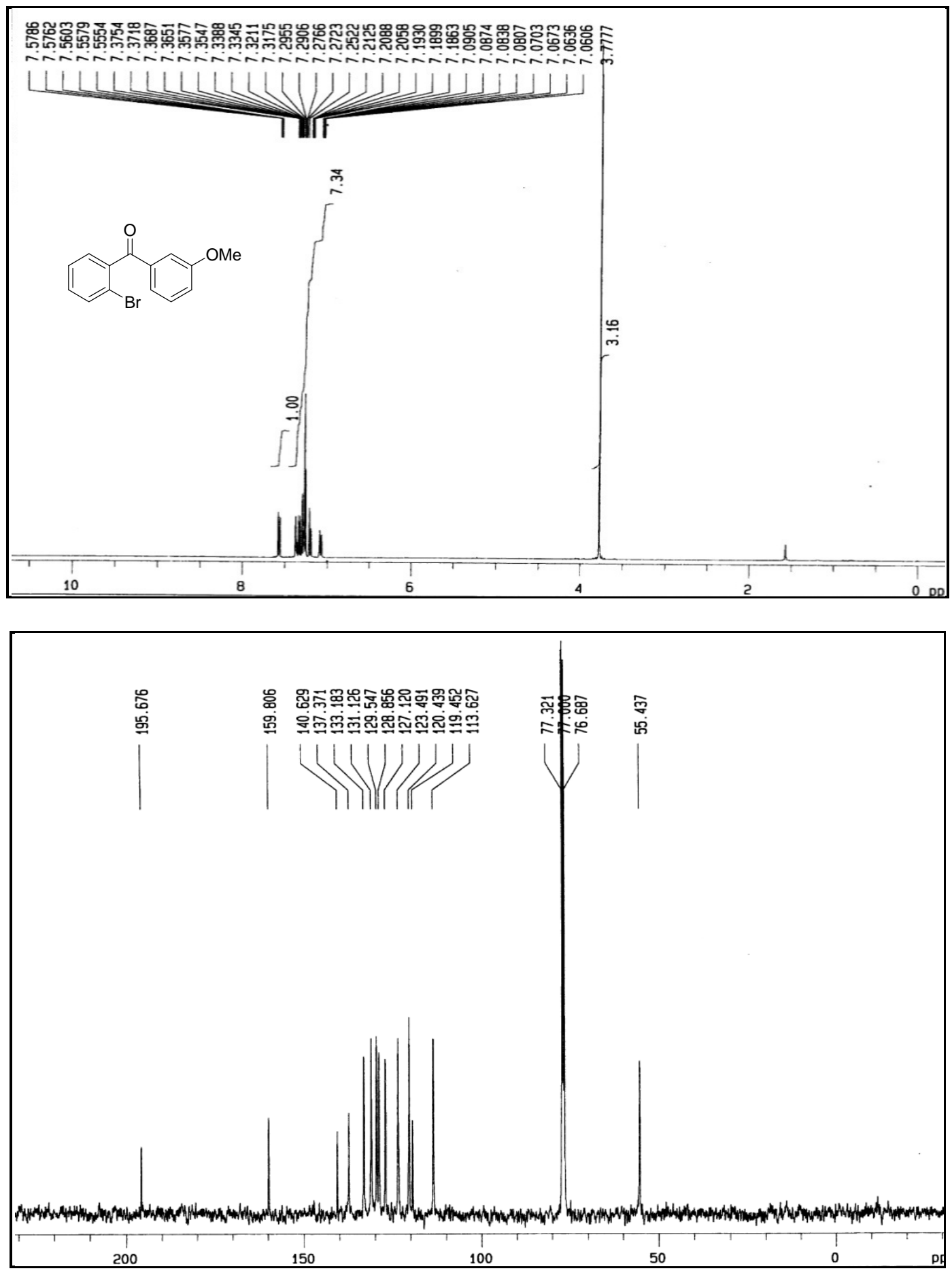

Figure S6. ${ }^{1} \mathrm{H}$ and ${ }^{13} \mathrm{C}$ NMR spectra of 2-bromo-3'-methoxybenzophenone 3d. 

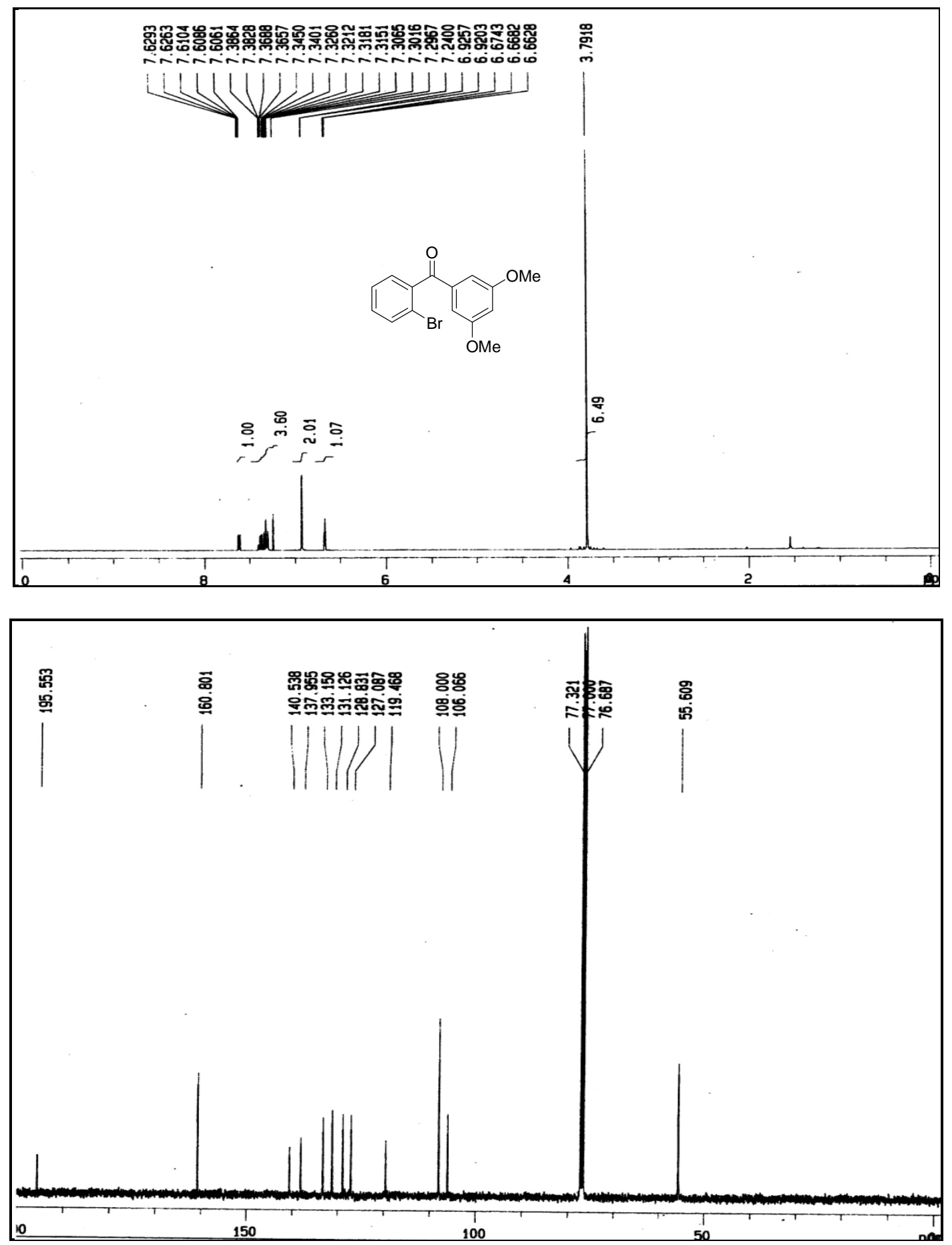

Figure S7. ${ }^{1} \mathrm{H}$ and ${ }^{13} \mathrm{C}$ NMR spectra of 2-bromo-3',5'-dimethoxybenzophenone 3e. 

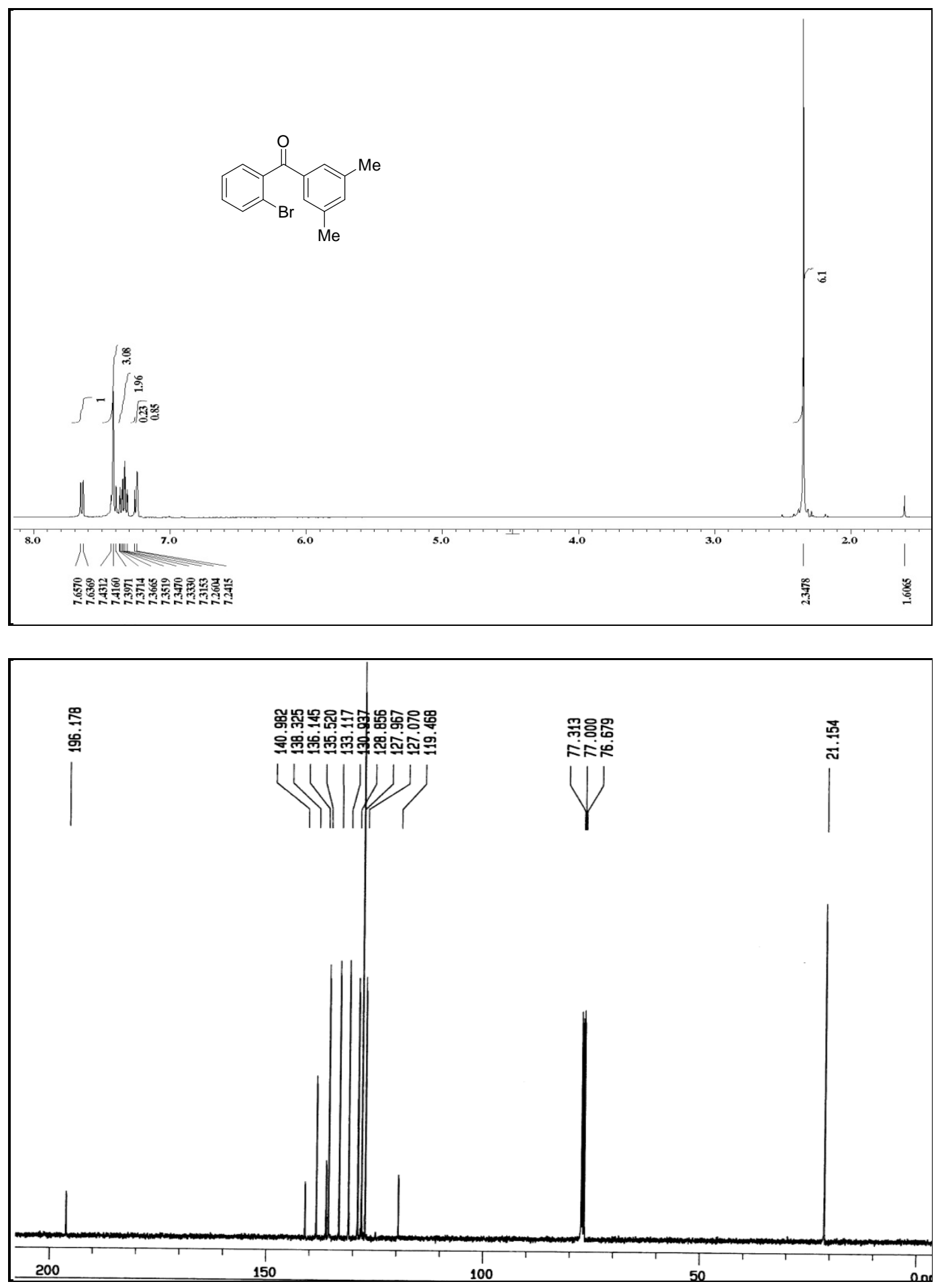

Figure S8. ${ }^{1} \mathrm{H}$ and ${ }^{13} \mathrm{C}$ NMR spectra of 2-bromo-3',5'-dimethylbenzophenone $3 \mathbf{f}$. 

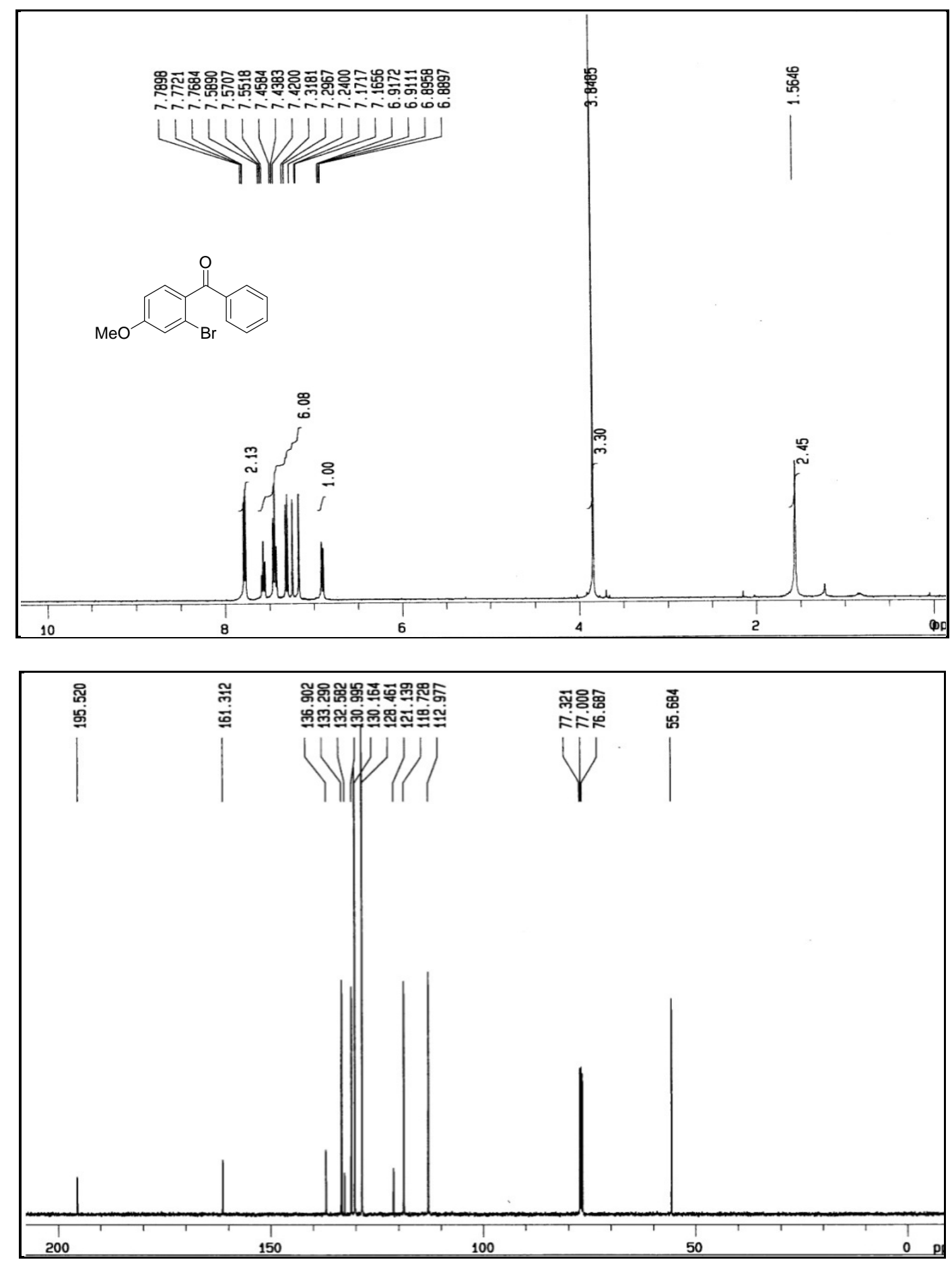

Figure S9. ${ }^{1} \mathrm{H}$ and ${ }^{13} \mathrm{C}$ NMR spectra of 2-bromo-4-methoxybenzophenone 4a. 



Figure S10. ${ }^{1} \mathrm{H}$ and ${ }^{13} \mathrm{C}$ NMR spectra of 2-bromo-4,4'-dimethoxybenzophenone $\mathbf{4 b}$. 

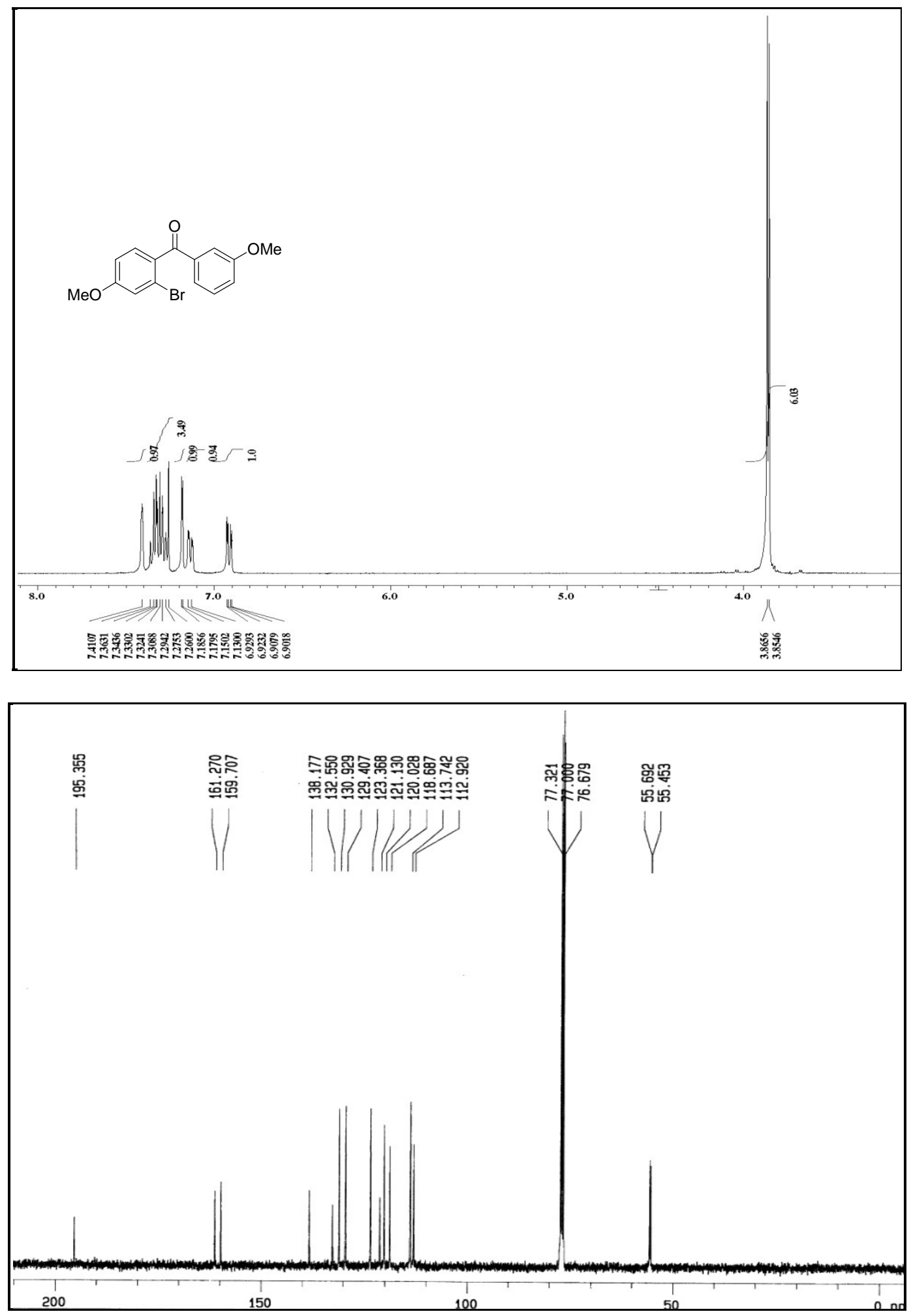

Figure S11. ${ }^{1} \mathrm{H}$ and ${ }^{13} \mathrm{C}$ NMR spectra of 2-bromo-3',4-dimethoxybenzophenone 4c. 

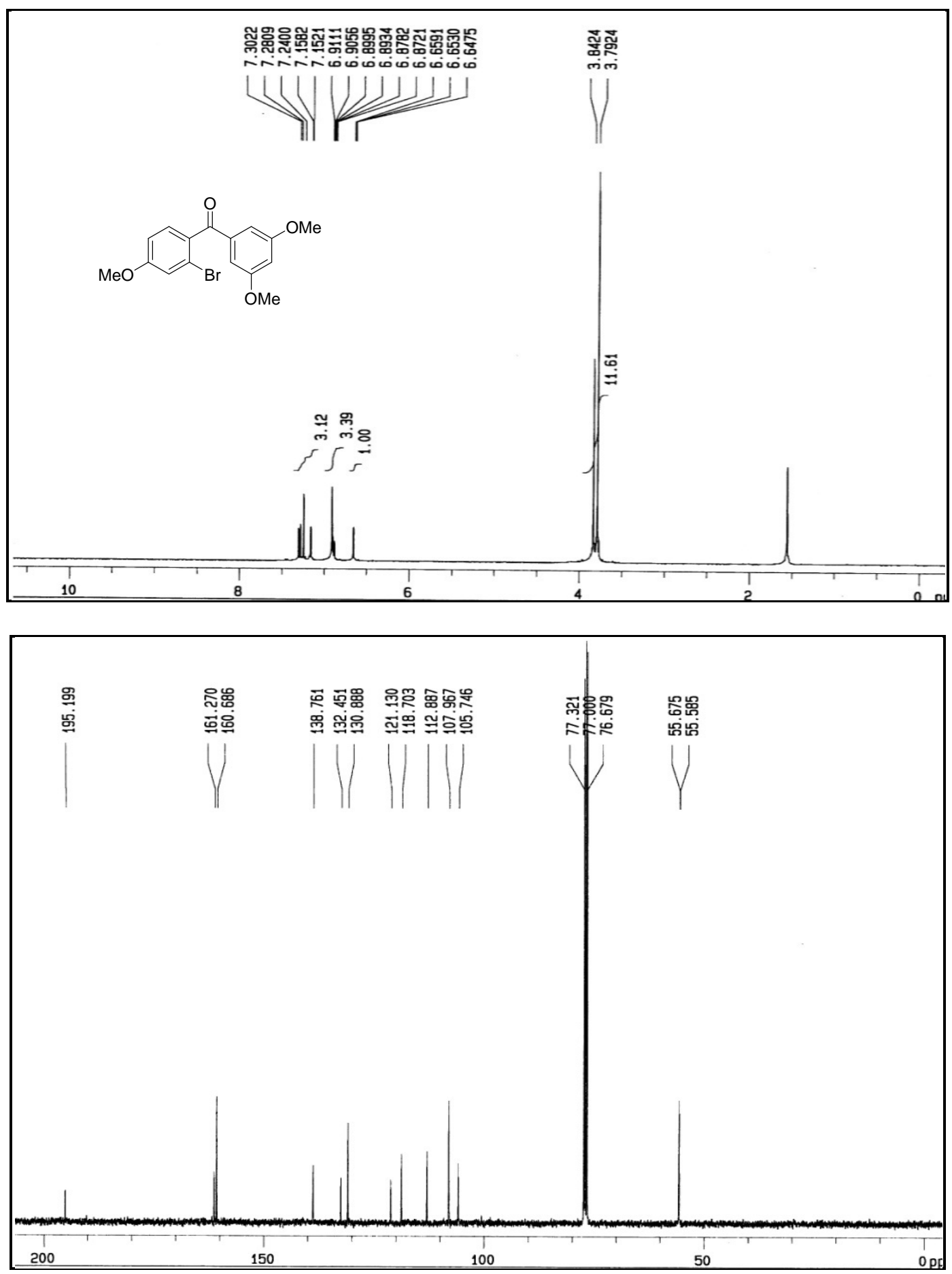

Figure S12. ${ }^{1} \mathrm{H}$ and ${ }^{13} \mathrm{C}$ NMR spectra of 2-bromo-3',4,5'-trimethoxybenzophenone 4d. 

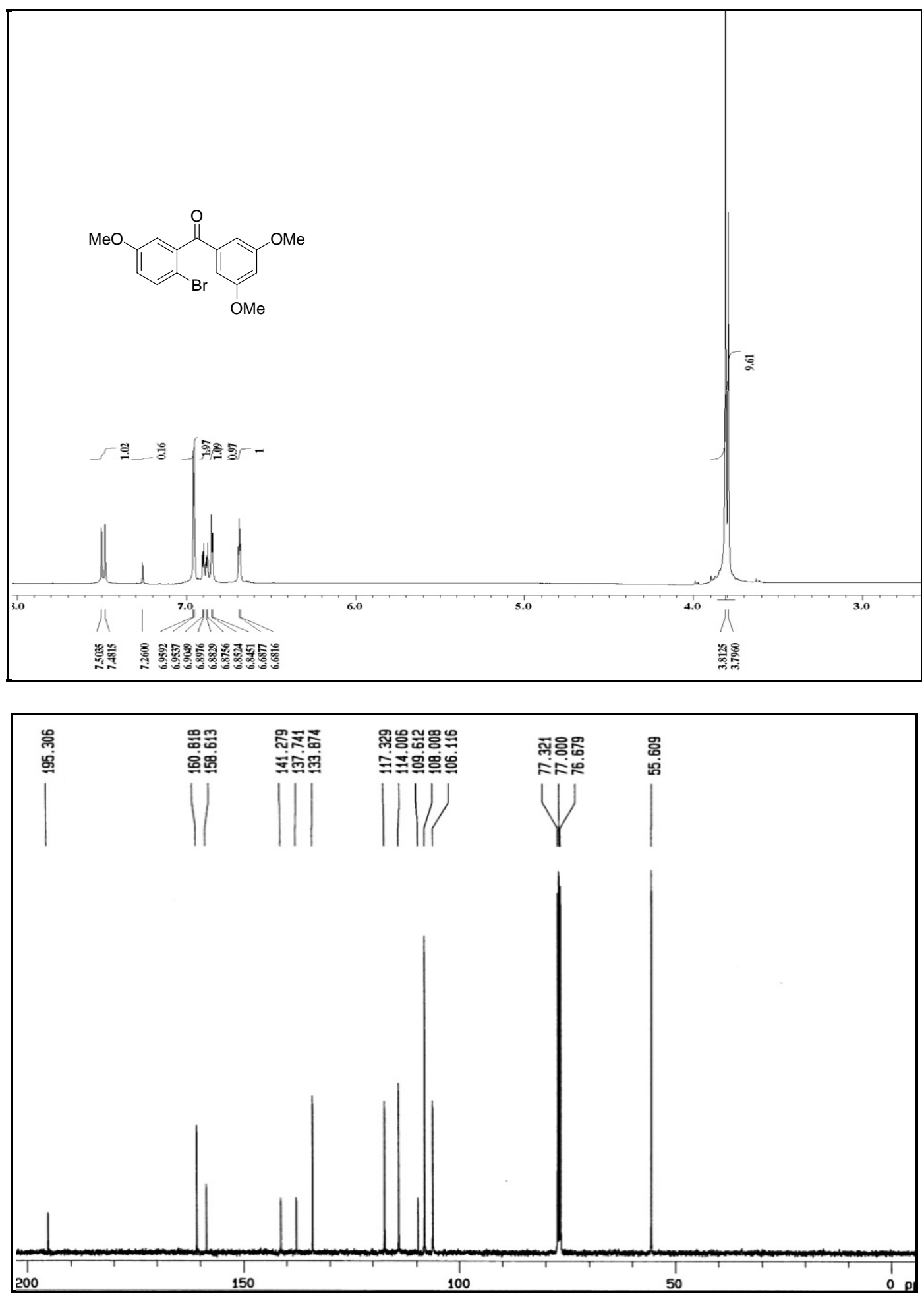

Figure S13. ${ }^{1} \mathrm{H}$ and ${ }^{13} \mathrm{C}$ NMR spectra of 2-bromo-3',5,5'-trimethoxybenzophenone 5. 

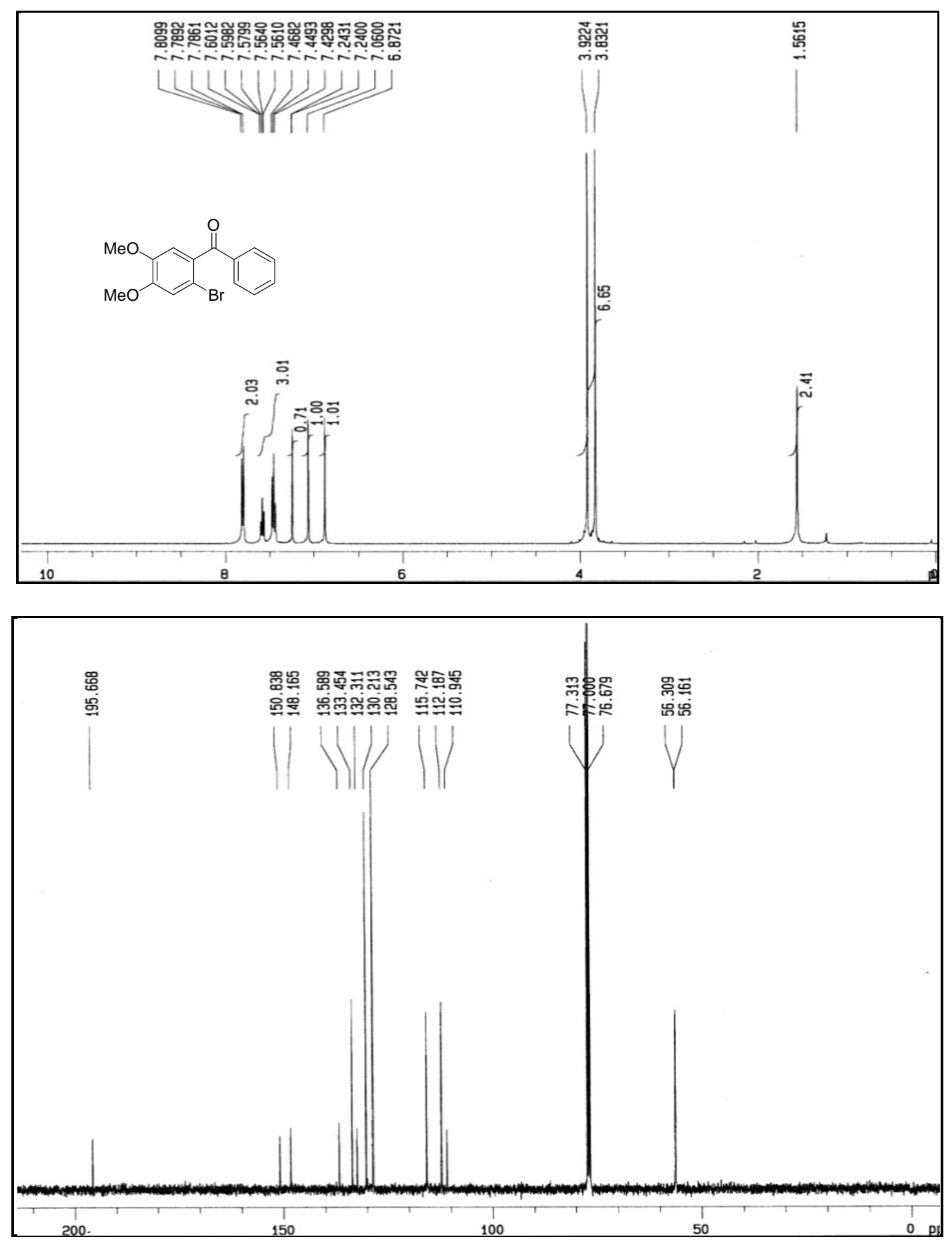

Figure S14. ${ }^{1} \mathrm{H}$ and ${ }^{13} \mathrm{C}$ NMR spectra of 2-bromo-4,5-dimethoxybenzophenone $6 \mathbf{a}$. 

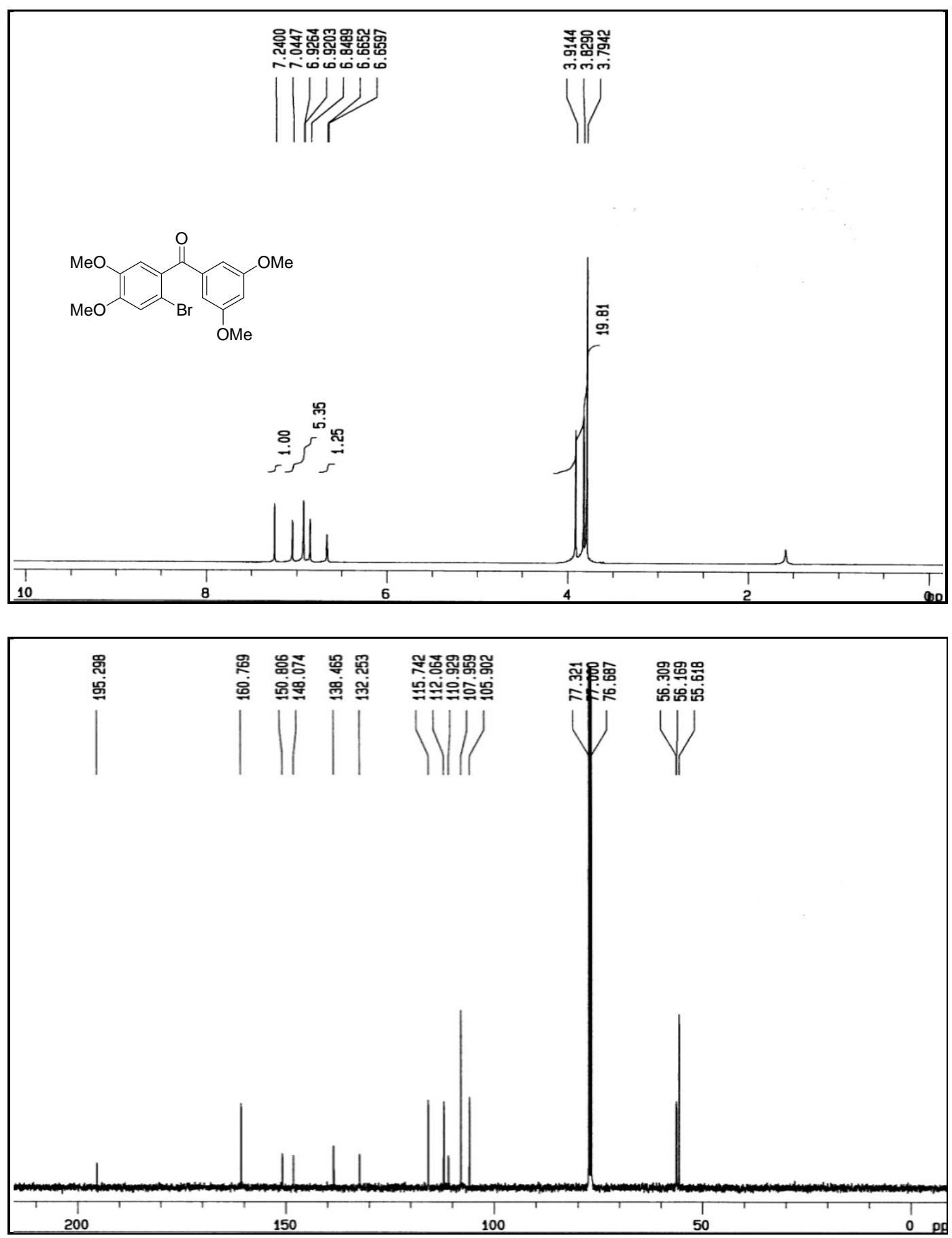

Figure S15. ${ }^{1} \mathrm{H}$ and ${ }^{13} \mathrm{C}$ NMR spectra of 2-bromo-3',4,5,5'-tetramethoxybenzophenone $\mathbf{6 b}$. 

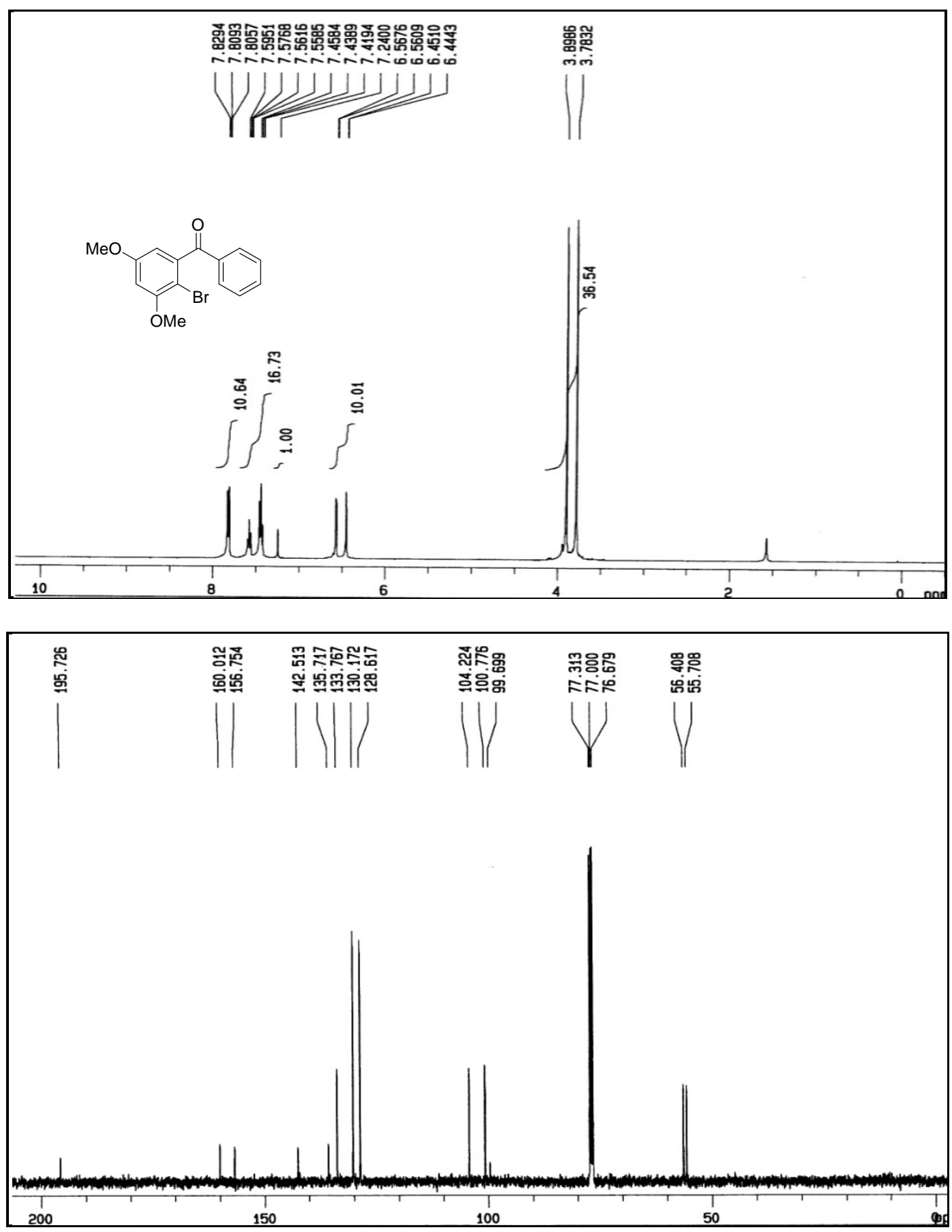

Figure S16. ${ }^{1} \mathrm{H}$ and ${ }^{13} \mathrm{C}$ NMR spectra of 2-bromo-3,5-dimethoxybenzophenone 7a. 

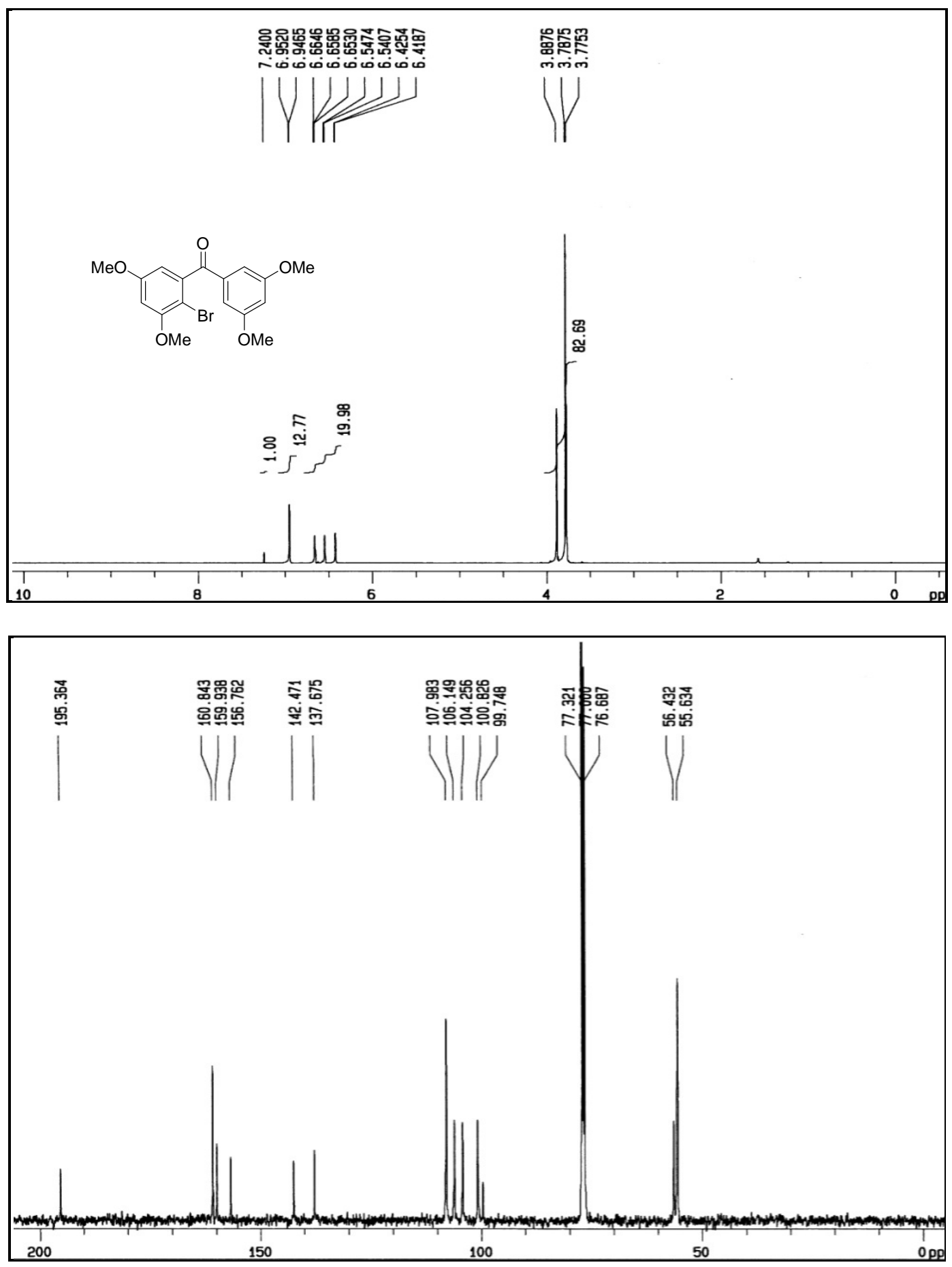

Figure S17. ${ }^{1} \mathrm{H}$ and ${ }^{13} \mathrm{C}$ NMR spectra of 2-bromo-3,3',5,5'-tetramethoxybenzophenone $7 \mathbf{b}$. 

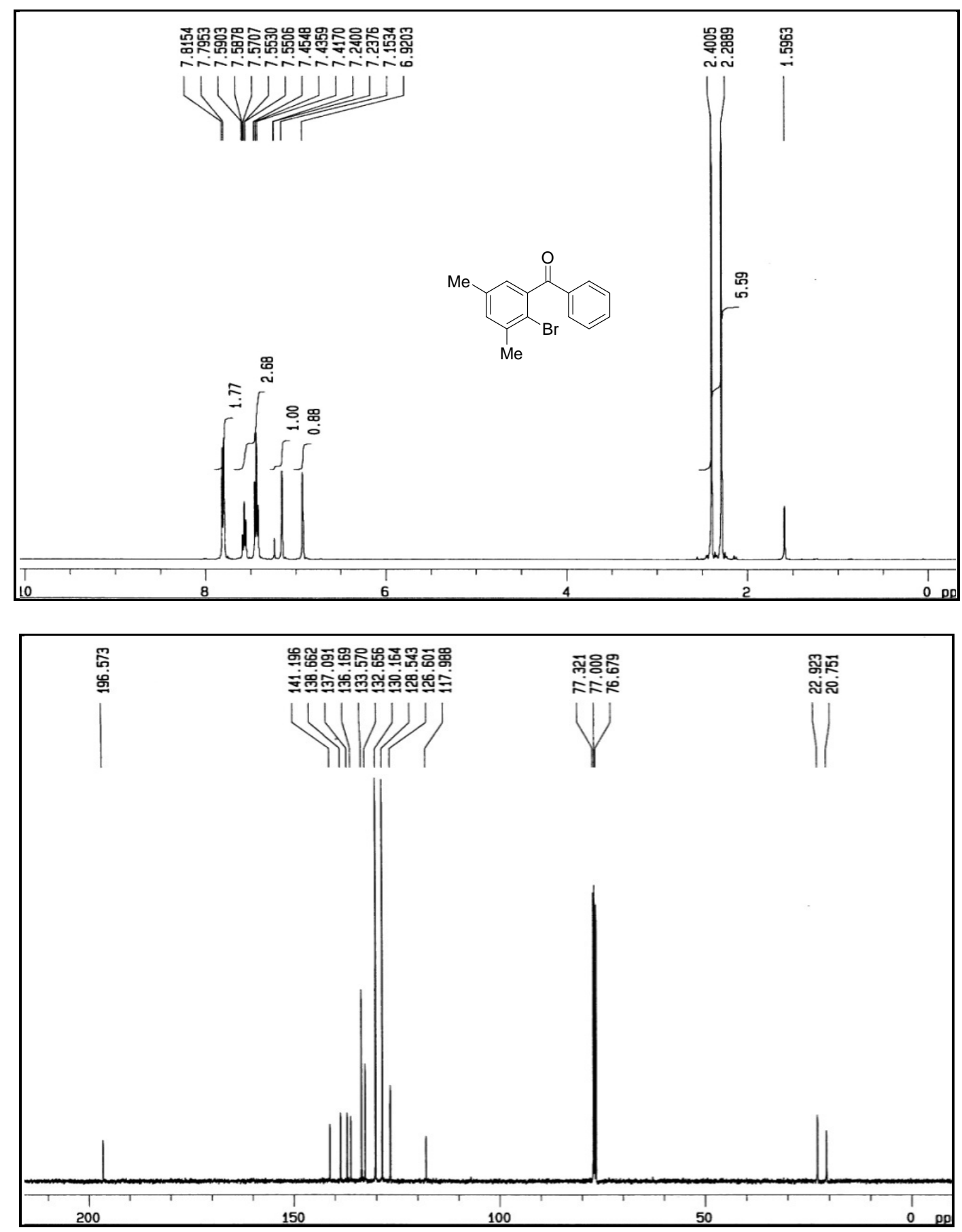

Figure S18. ${ }^{1} \mathrm{H}$ and ${ }^{13} \mathrm{C}$ NMR spectra of 2-bromo-3,5-dimethylbenzophenone $\mathbf{8 a}$. 

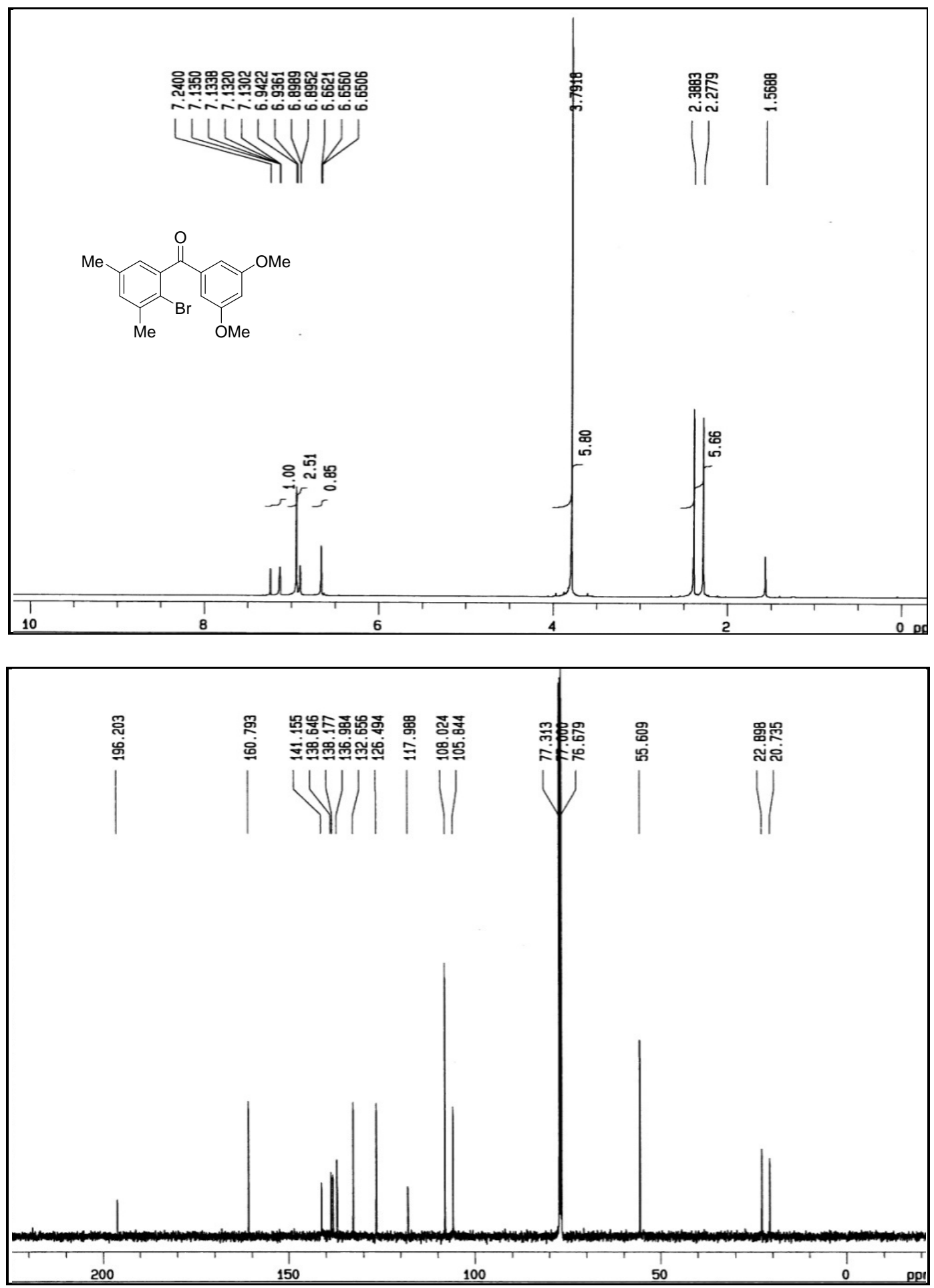

Figure S19. ${ }^{1} \mathrm{H}$ and ${ }^{13} \mathrm{C}$ NMR spectra of 2-bromo-3',5'-dimethoxy-3,5-dimethylbenzophenone $\mathbf{8 b}$. 

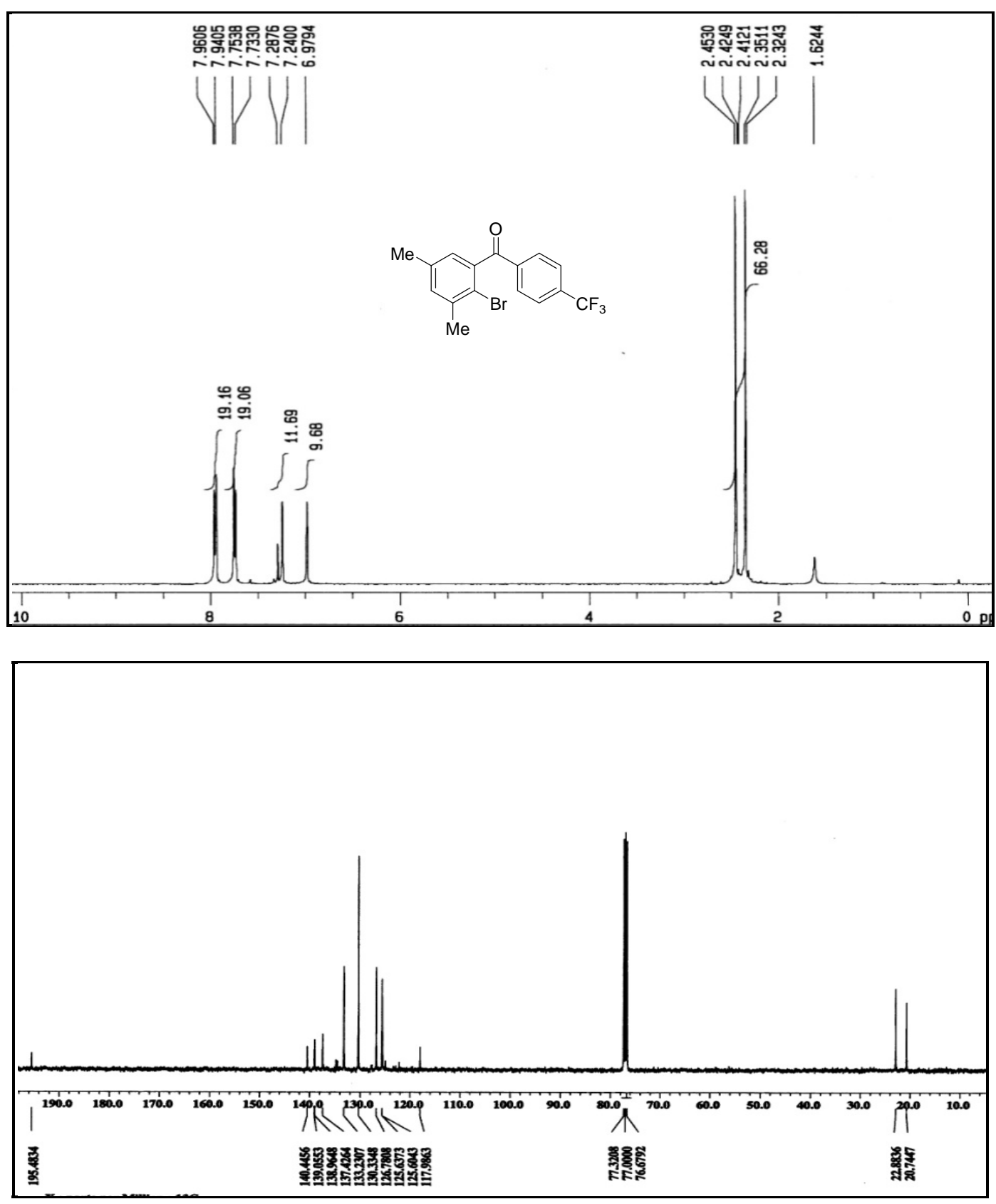

Figure S20. ${ }^{1} \mathrm{H}$ and ${ }^{13} \mathrm{C}$ NMR spectra of 2-bromo-3,5-dimethyl-4'-trifluoromethylbenzophenone 8c. 

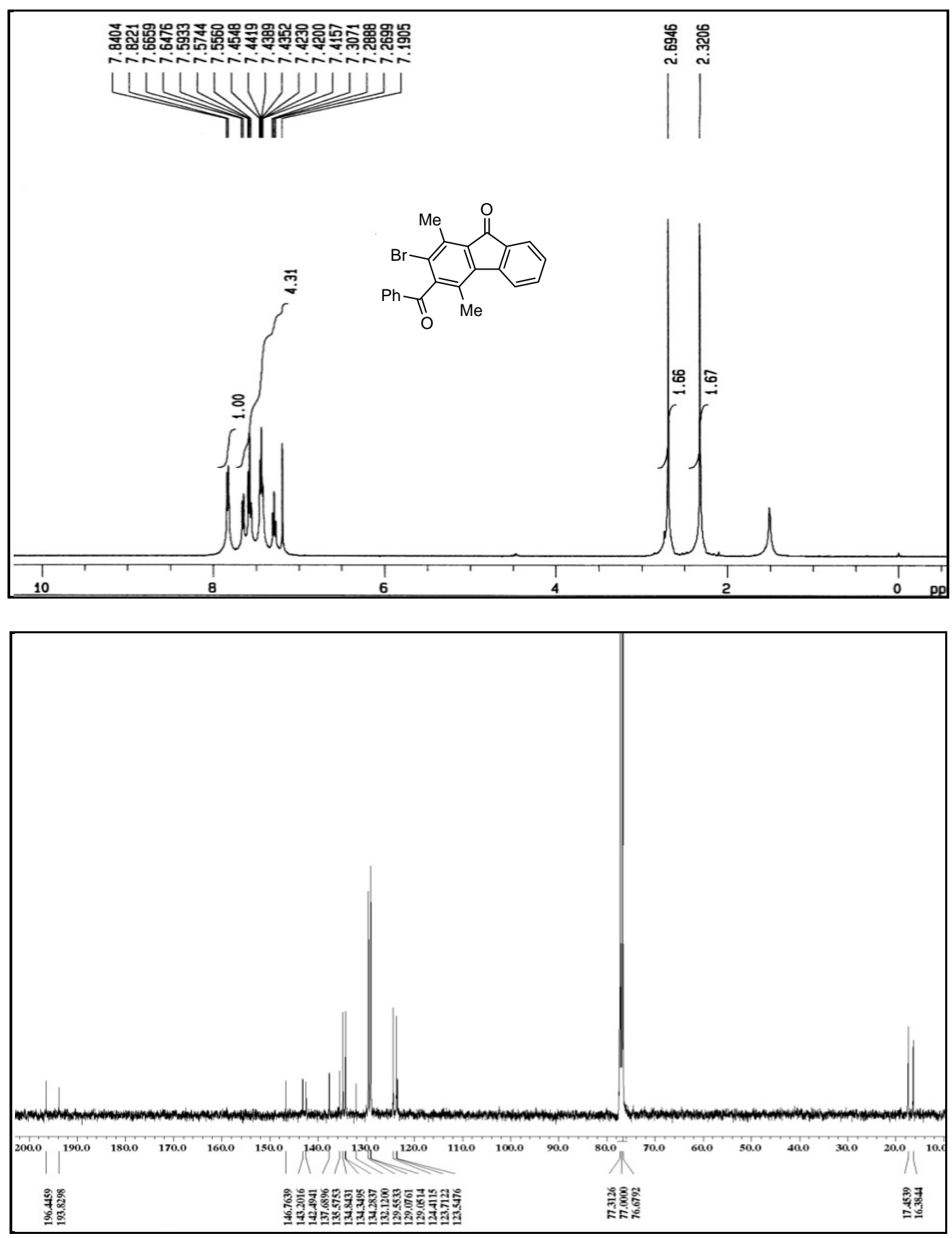

Figure S21. ${ }^{1} \mathrm{H}$ and ${ }^{13} \mathrm{C}$ NMR spectra of 3-benzoyl-2-bromo-1,4-dimethylfluoren9-one (2-FI). 

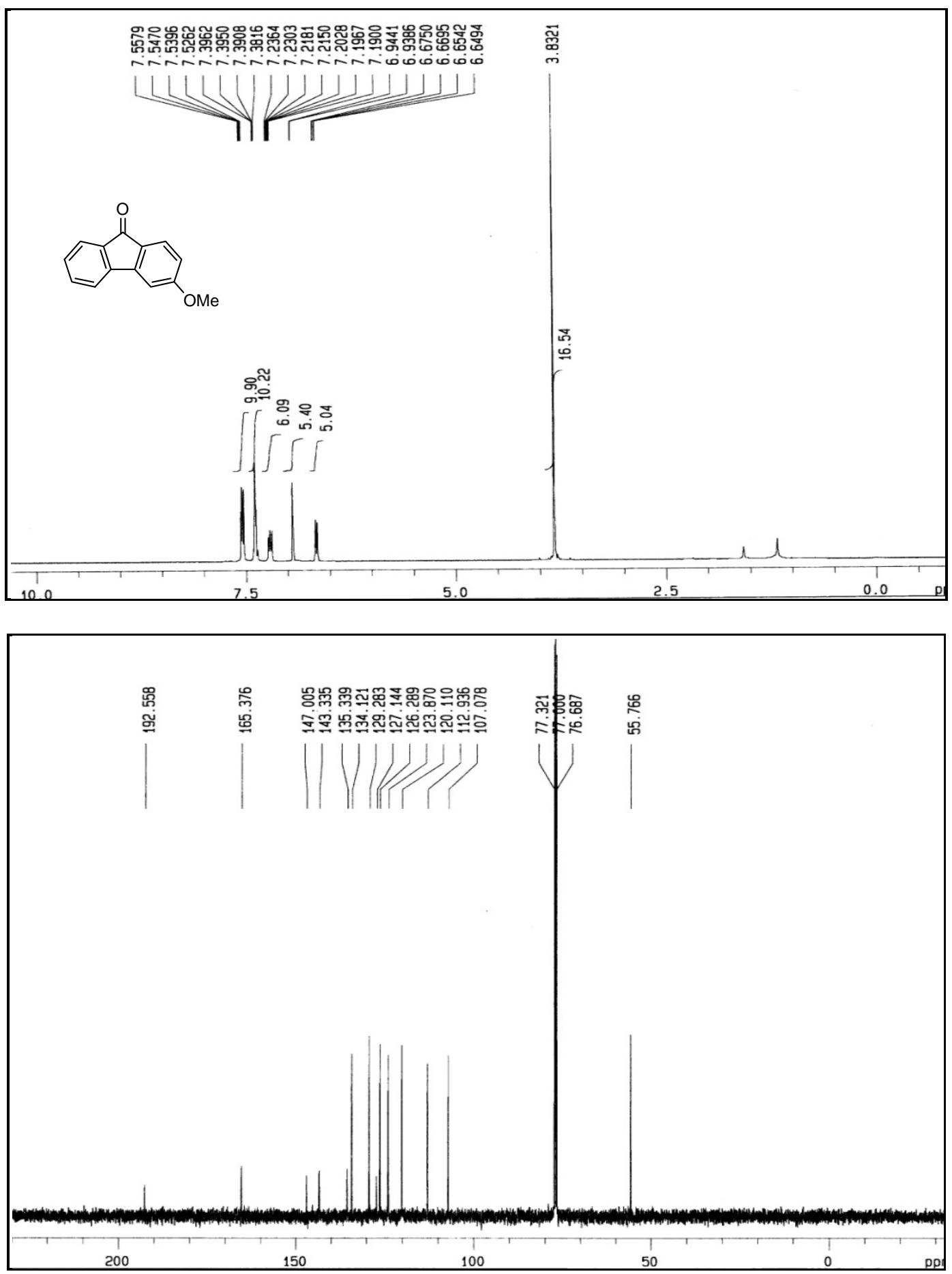

Figure S22. ${ }^{1} \mathrm{H}$ and ${ }^{13} \mathrm{C}$ NMR spectra of 3-methoxyfluoren-9-one (3b-Fl). 

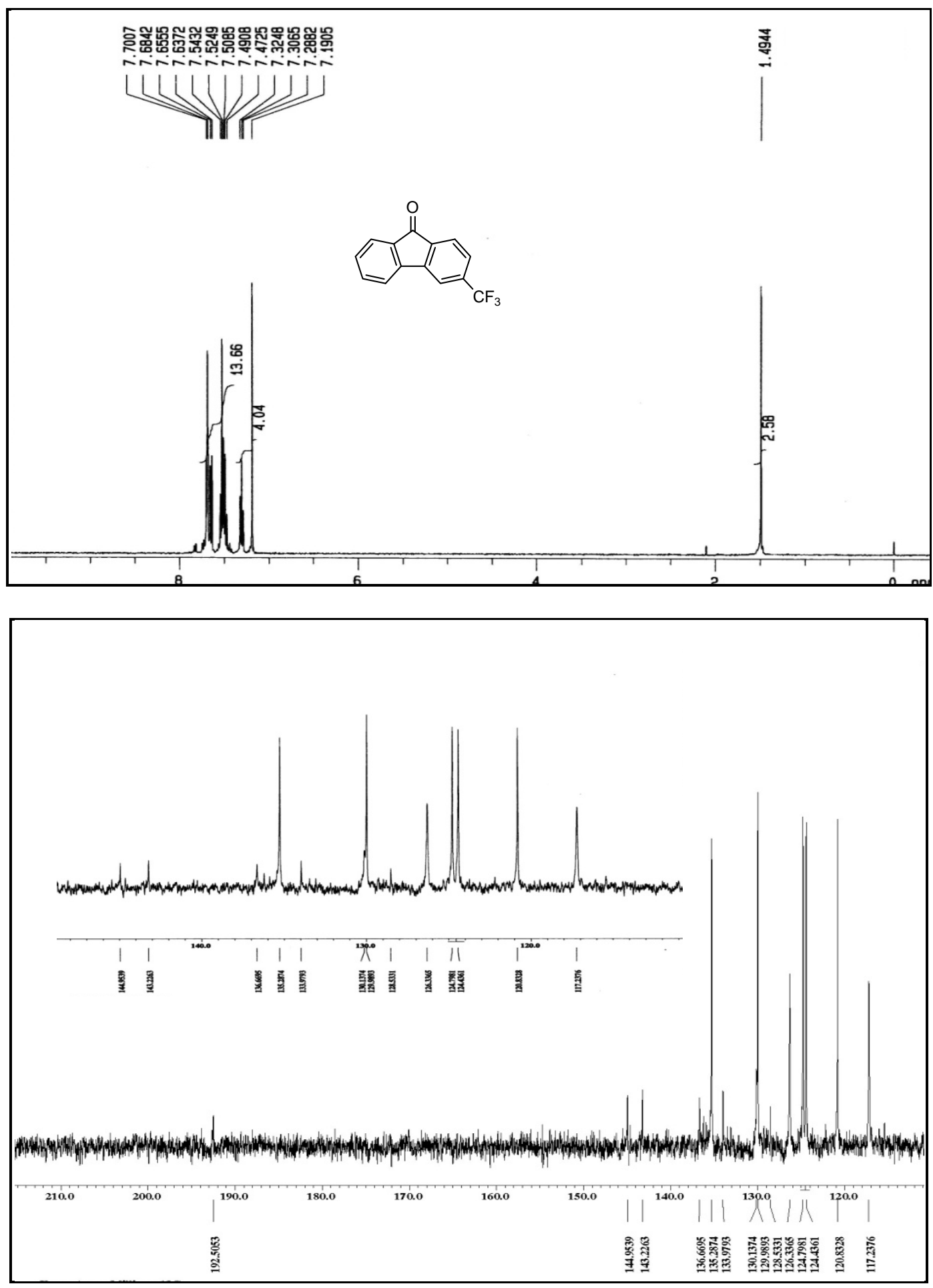

Figure S23. ${ }^{1} \mathrm{H}$ and ${ }^{13} \mathrm{C}$ NMR spectra of 3-trifluoromethylfluoren-9-one (3c-FI). 



Figure S24. ${ }^{1} \mathrm{H}$ and ${ }^{13} \mathrm{C}$ NMR spectra of 2-methoxyfluoren-9-one (3d-Fl). 

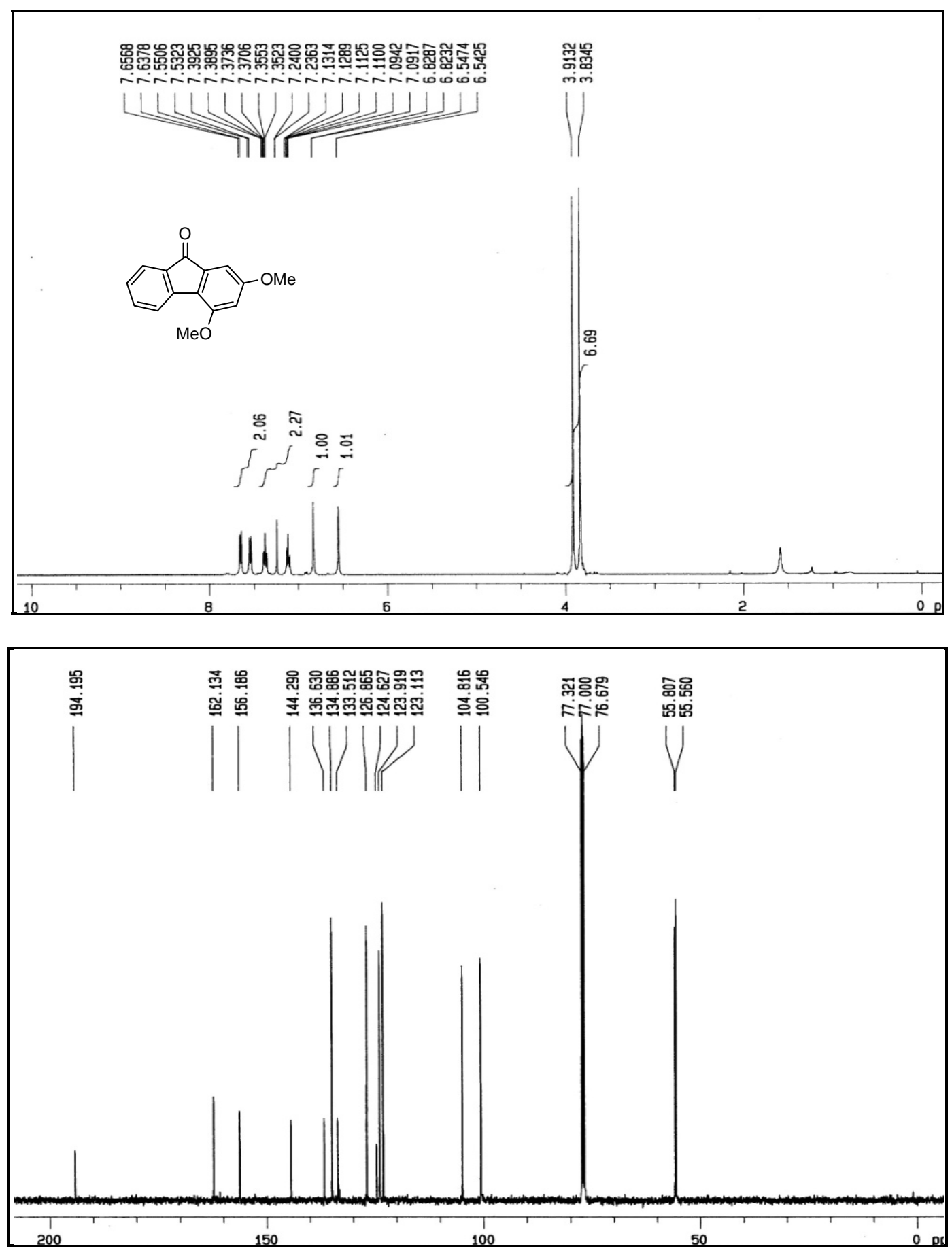

Figure S25. ${ }^{1} \mathrm{H}$ and ${ }^{13} \mathrm{C}$ NMR spectra of 2,4-dimethoxyfluoren-9-one (3e-Fl). 

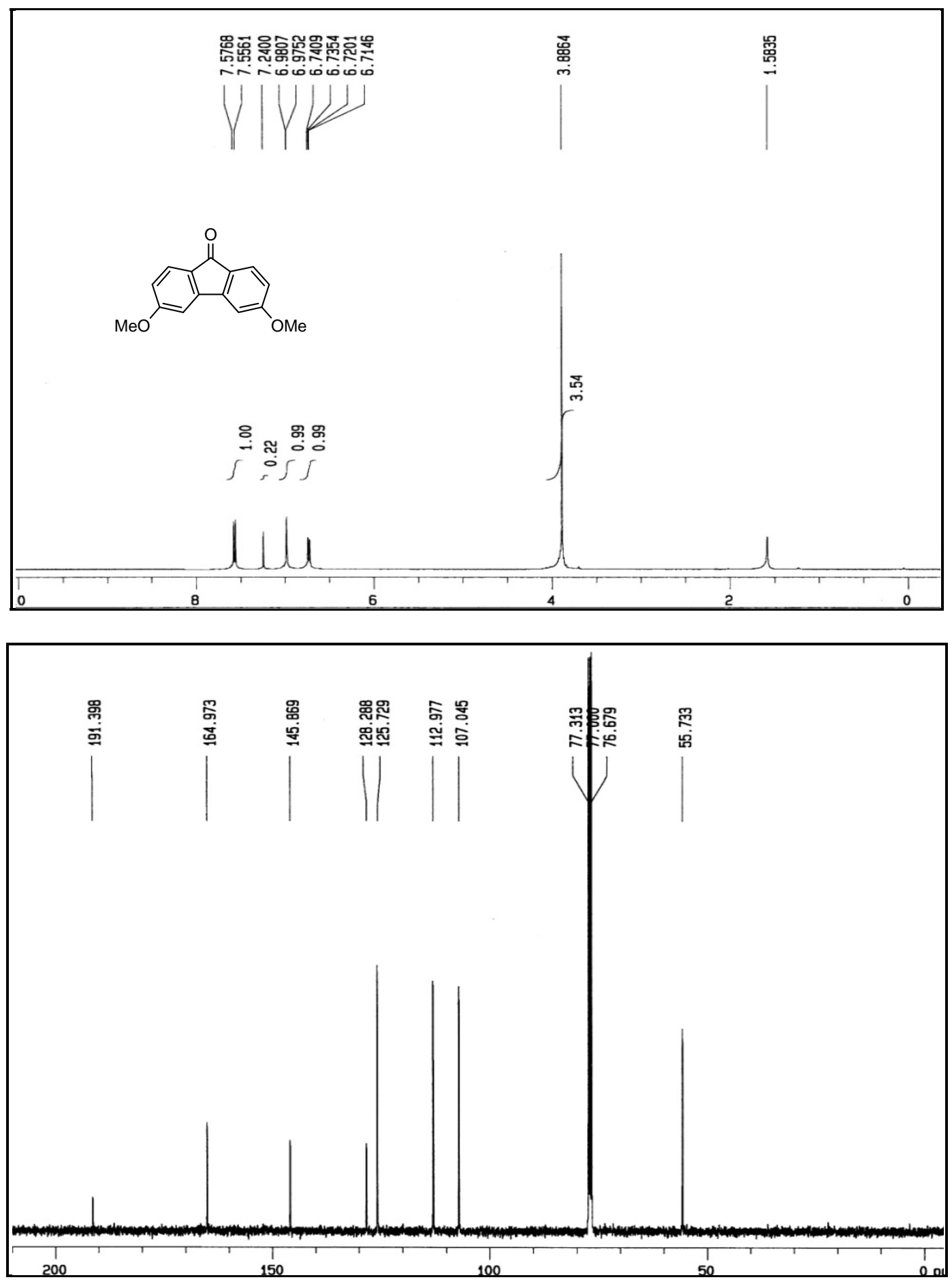

Figure S26. ${ }^{1} \mathrm{H}$ and ${ }^{13} \mathrm{C}$ NMR spectra of 3,6-dimethoxyfluoren-9-one (4b-Fl). 

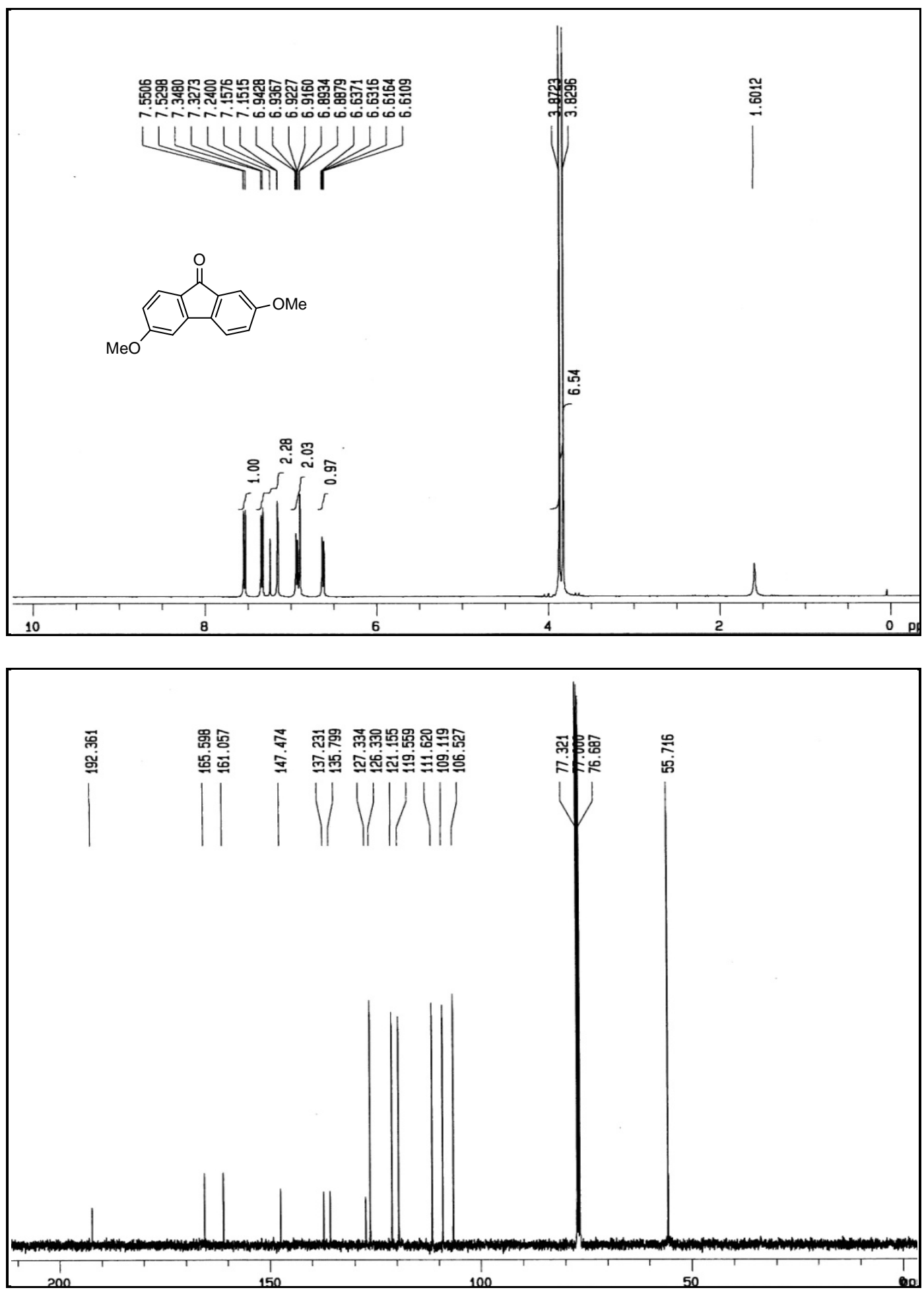

Figure S27. ${ }^{1} \mathrm{H}$ and ${ }^{13} \mathrm{C}$ NMR spectra of 2,6-dimethoxyfluoren-9-one (4c-Fl). 

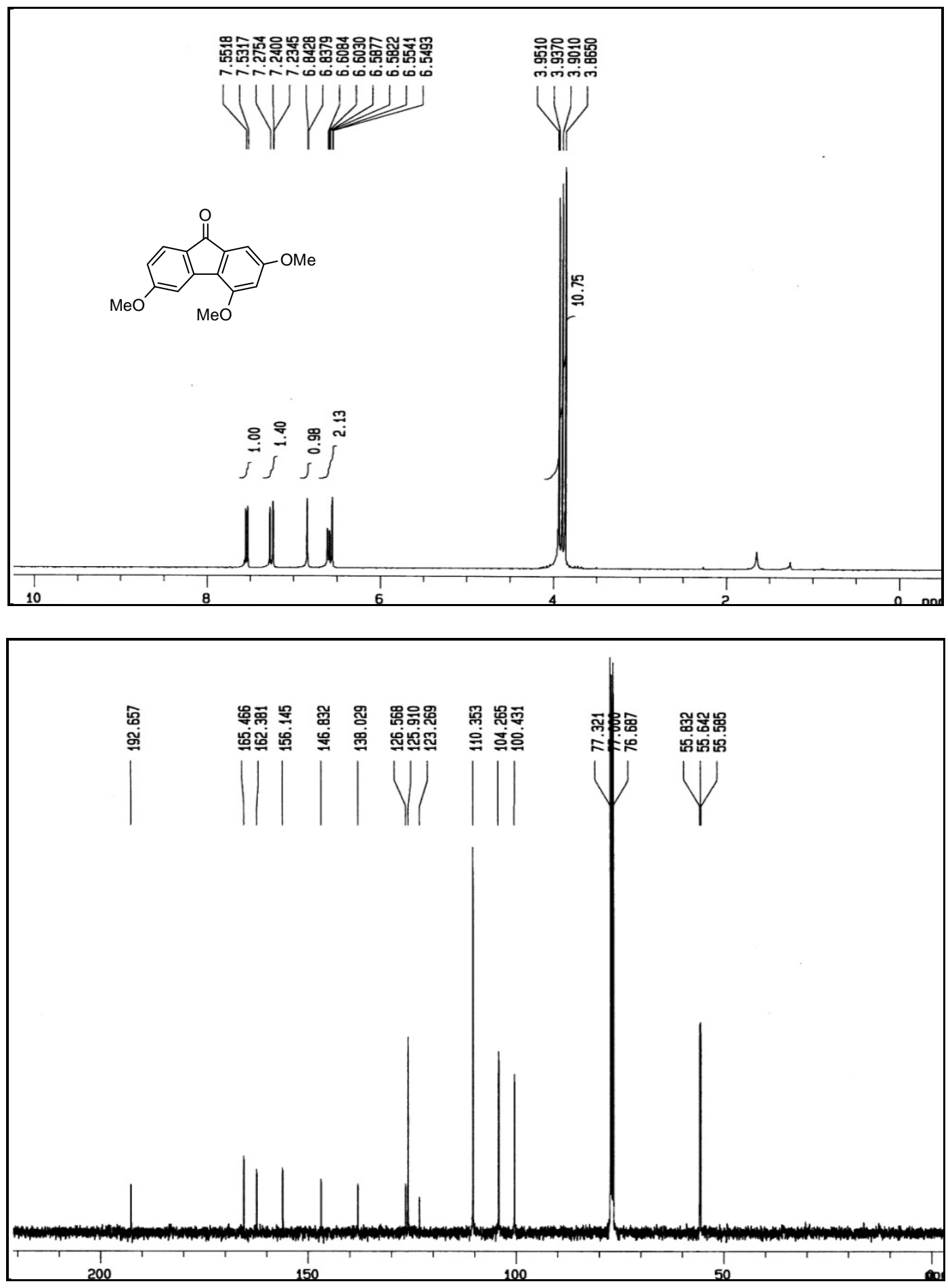

Figure S28. ${ }^{1} \mathrm{H}$ and ${ }^{13} \mathrm{C}$ NMR spectra of 2,4,6-trimethoxyfluoren-9-one (4d-Fl). 

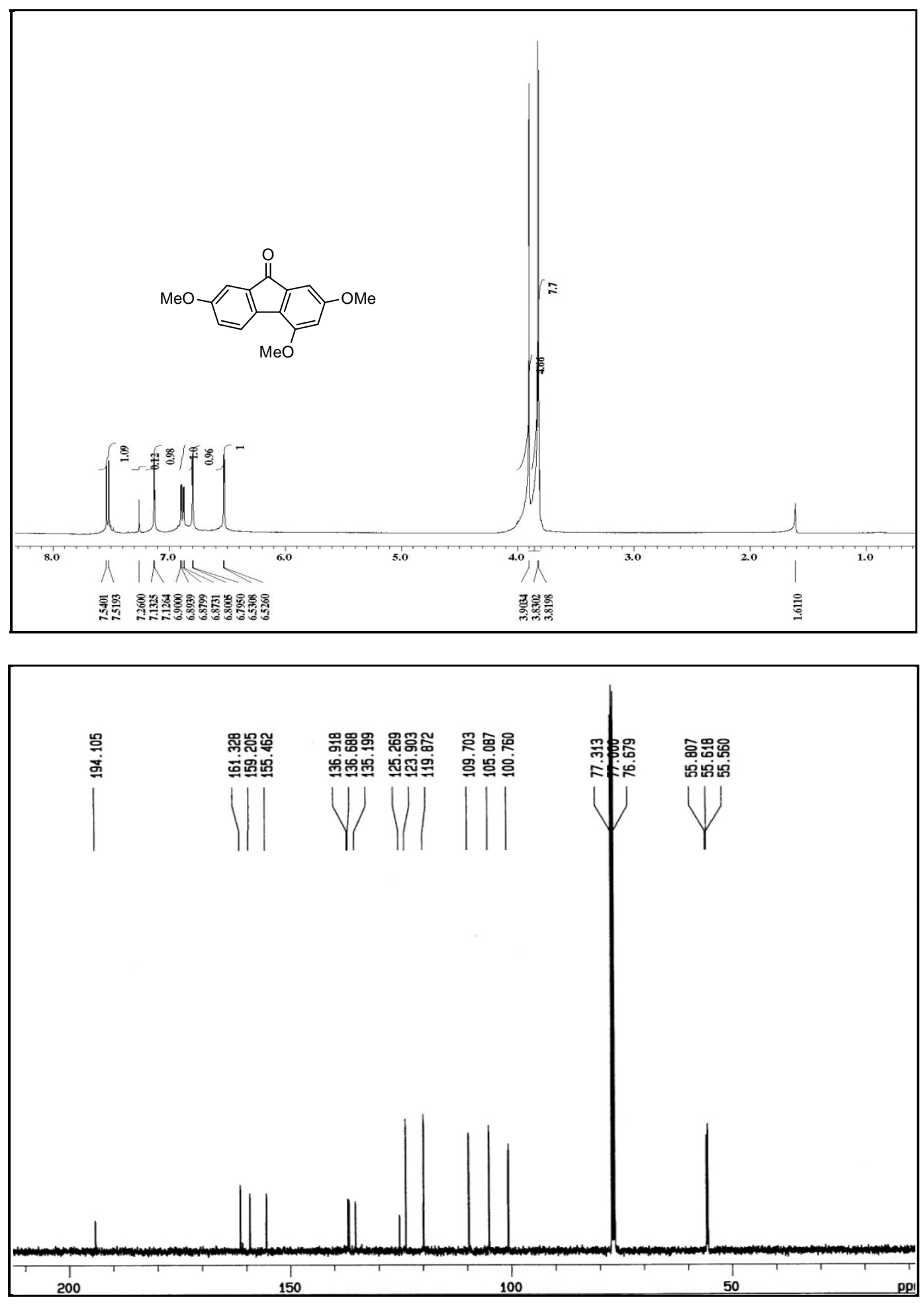

Figure S29. ${ }^{1} \mathrm{H}$ and ${ }^{13} \mathrm{C}$ NMR spectra of 2,4,7-trimethoxyfluoren-9-one (5-FI). 

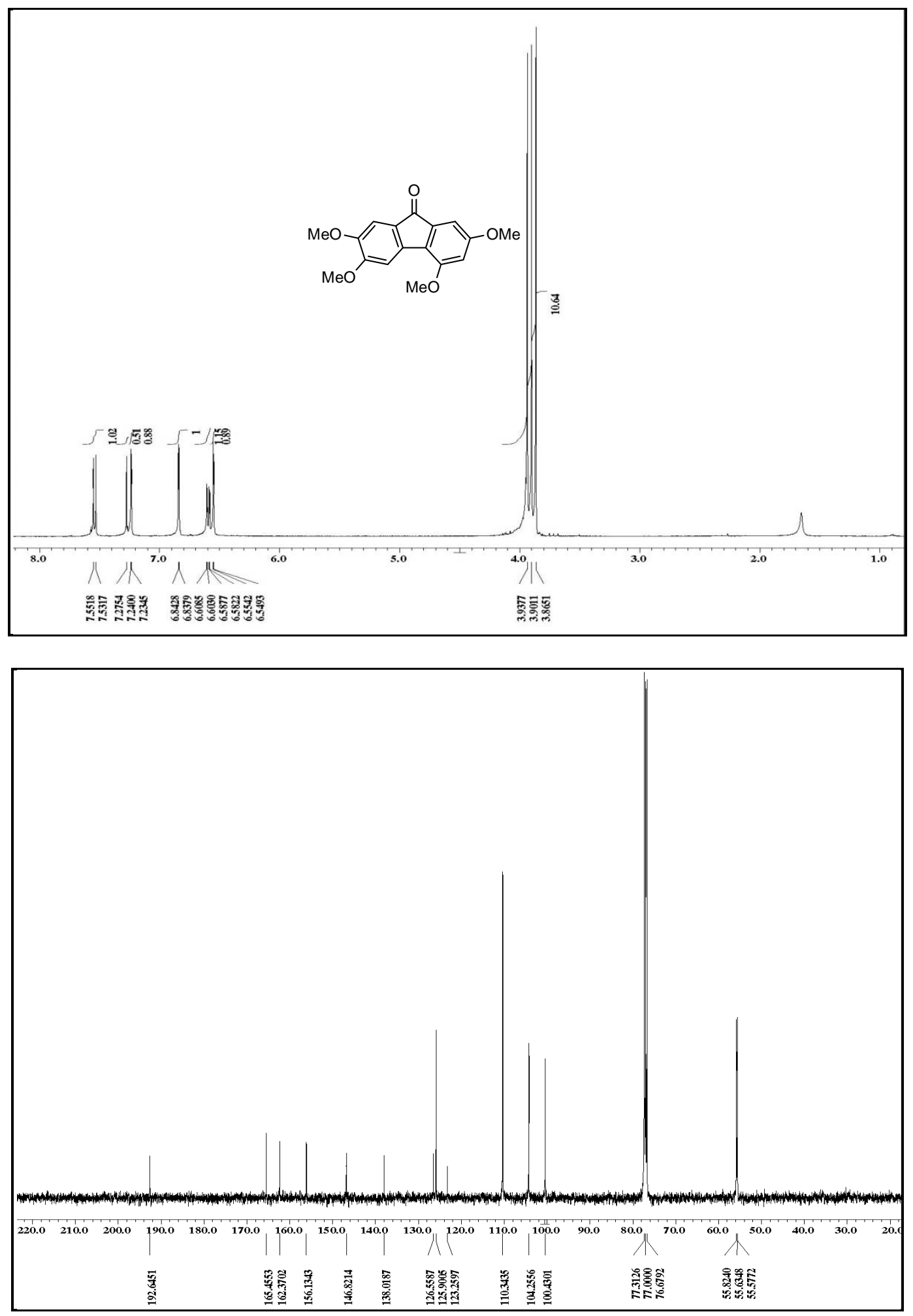

Figure S30. ${ }^{1} \mathrm{H}$ and ${ }^{13} \mathrm{C}$ NMR spectra of 2,3,5,6-tetramethoxyfluoren-9-one (6b-Fl). 

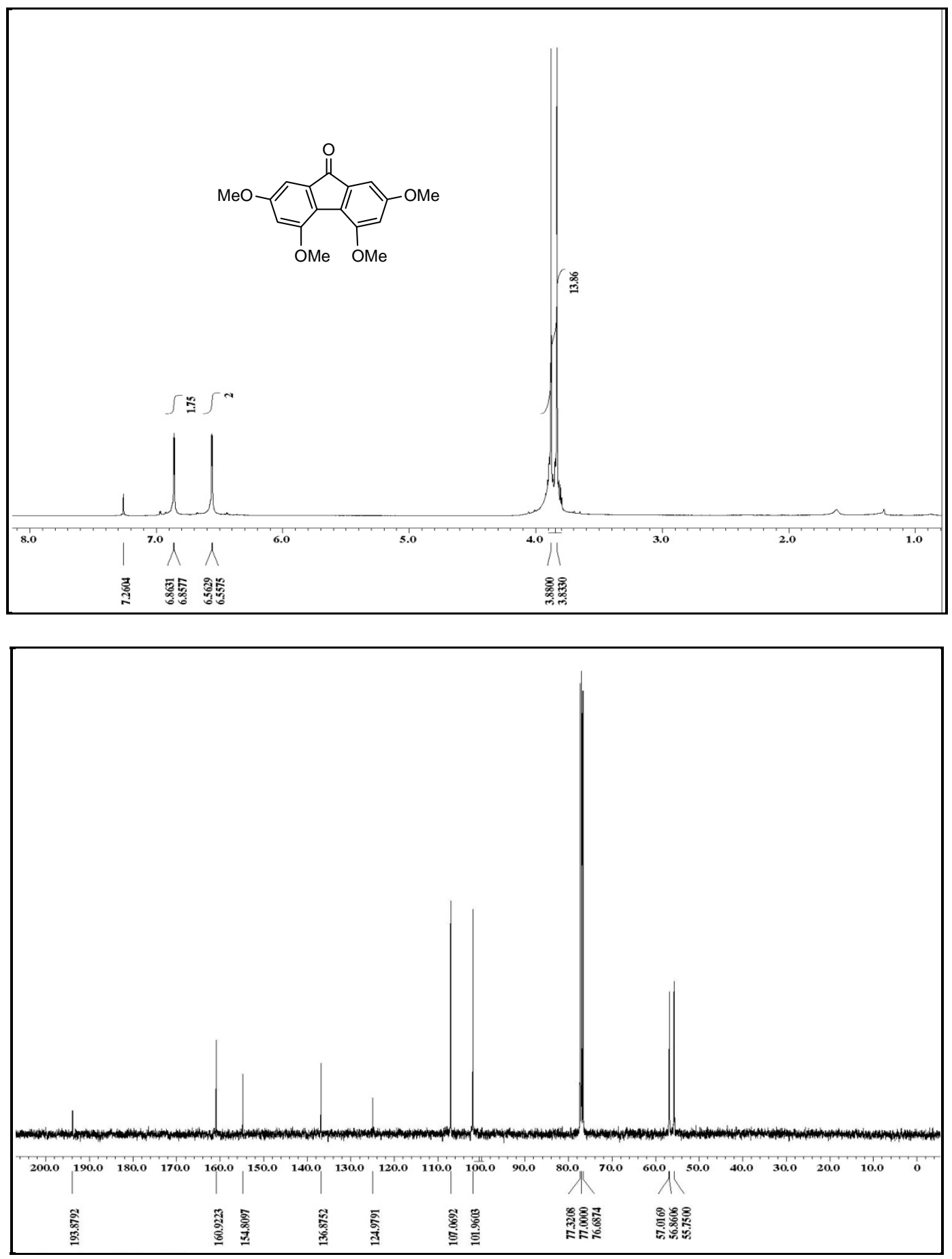

Figure S31. ${ }^{1} \mathrm{H}$ and ${ }^{13} \mathrm{C}$ NMR spectra of 2,4,5,7-tetramethoxyfluoren-9-one (7b-Fl). 

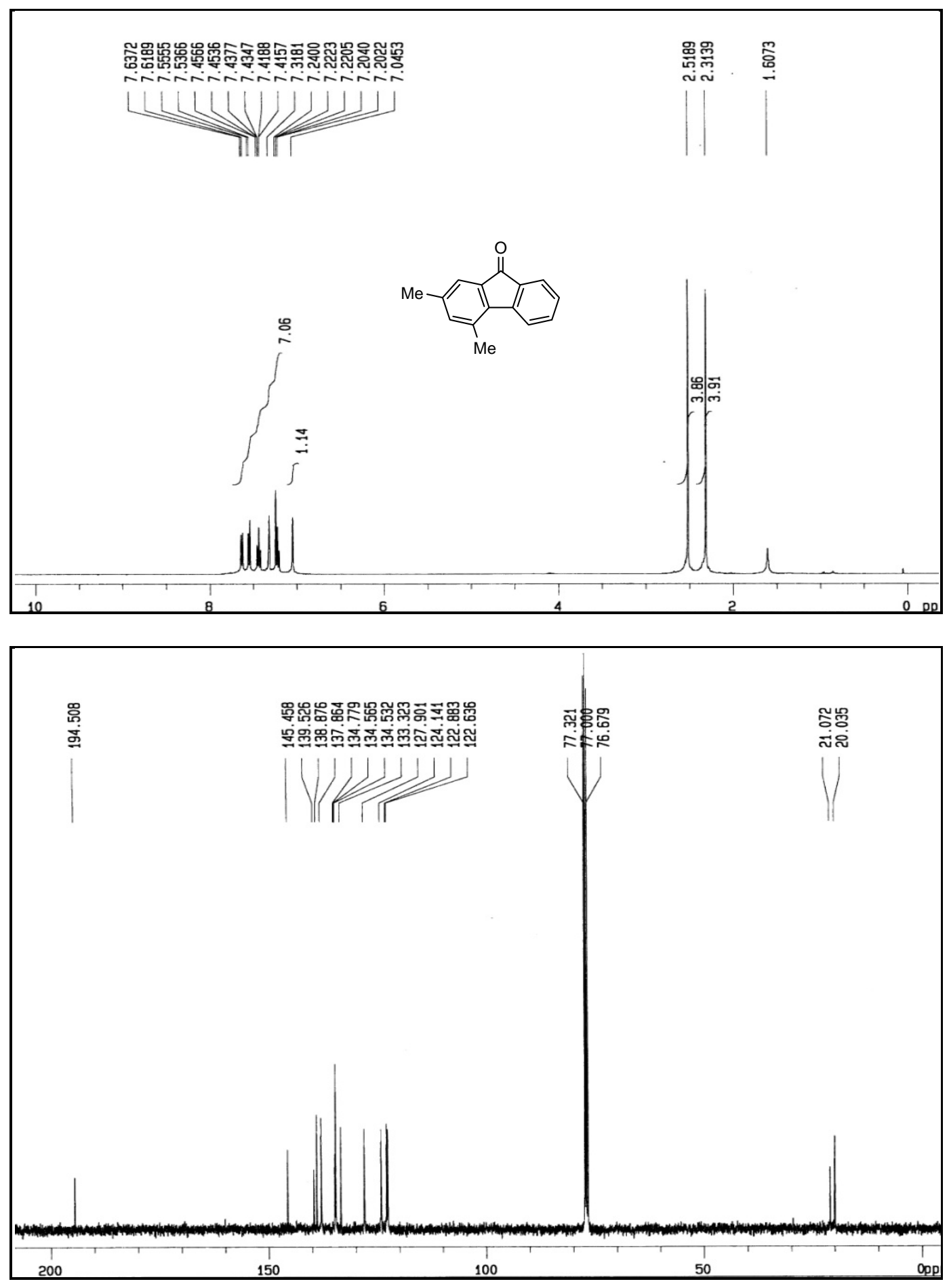

Figure S32. ${ }^{1} \mathrm{H}$ and ${ }^{13} \mathrm{C}$ NMR spectra of 2,4-dimethylfluoren-9-one (8a-Fl). 

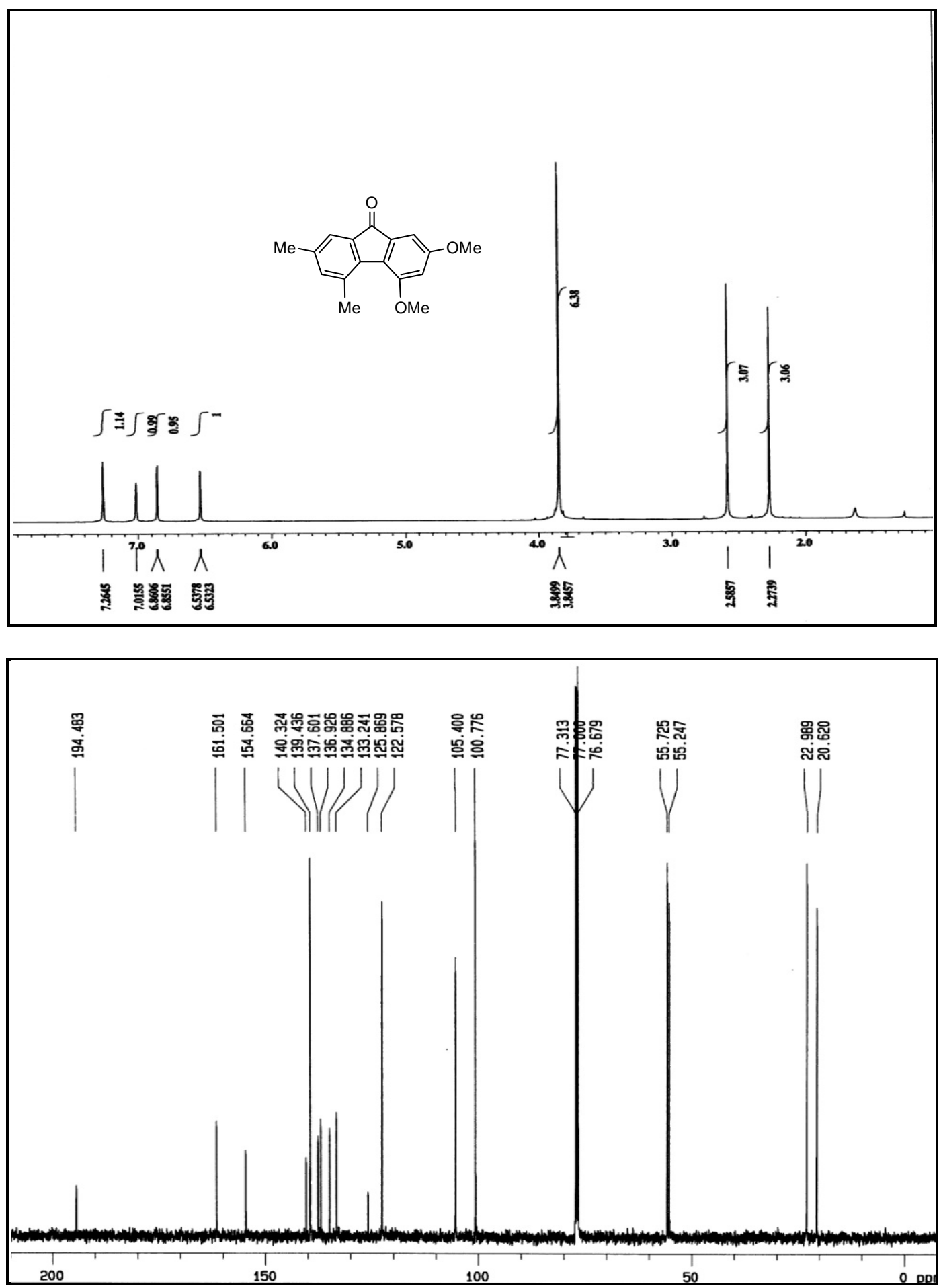

Figure S33. ${ }^{1} \mathrm{H}$ and ${ }^{13} \mathrm{C}$ NMR spectra of 2,4-dimethoxy-5,7-dimethylfluoren-9-one (8b-Fl). 



Figure S34. ${ }^{1} \mathrm{H}$ and ${ }^{13} \mathrm{C}$ NMR spectra of 2,4-dimethoxy-6-trifluoromethylfluoren-9-one (8c-Fl). 

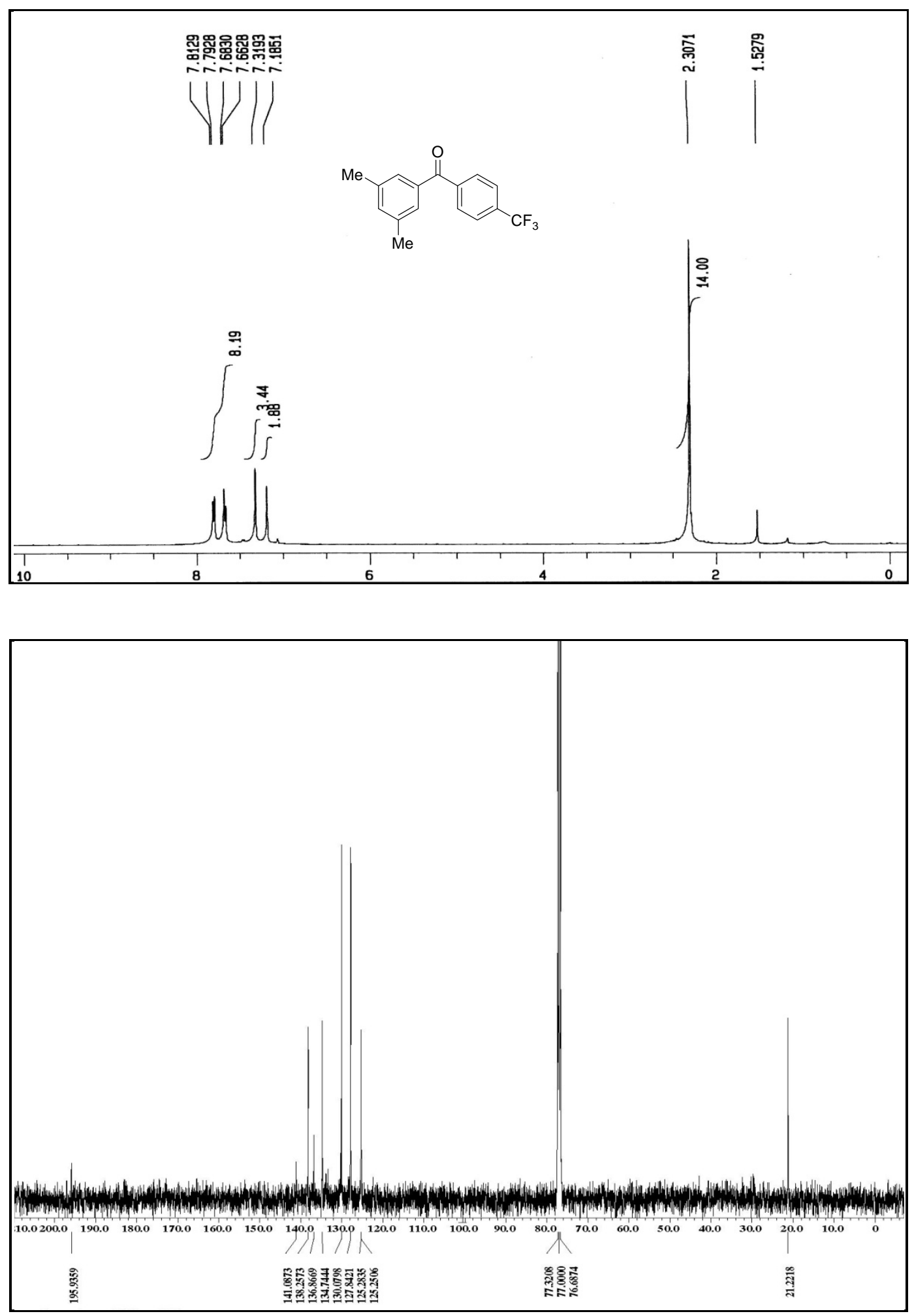

Figure S35. ${ }^{1} \mathrm{H}$ and ${ }^{13} \mathrm{C}$ NMR spectra of 3,5-dimethoxy-4'-trifluoromethylbenzophenone (8cBp). 